\title{
Effects of fabric retrofit insulation in a UK high-rise social housing building on temperature take-back
}

\author{
${ }^{a}$ School of Architecture Planning $\&$ Landscape, Newcastle University \\ Newcastle upon Tyne, UK, NE1 7RU
}

\begin{abstract}
This paper presents a two year long empirical study on the effects of fabric retrofit insulation on a high rise social housing building (a 23- storey block with 157 flats) in Newcastle upon Tyne (UK). The study has followed a quasi-experimental approach coupled with qualitative methods and examines whether temperature take-back is taking place; whether it operates independently of socio economic characteristics due to saturation effects; and the relationship between temperature take-back, physical factors and occupant's behavioural change. The presented empirical evidence suggests that, first, temperature take-back as extra warmth (or energy consumption savings) is not occurring. Second, the saturation effect has taken place. This supports the assumption that temperature take-back decreases owing to saturation effects when pre-intervention internal temperatures saturate (approaching $21^{\circ} \mathrm{C}$ ) in lieu of the hypothesis that low-income householders take the benefits of an energy efficiency intervention as extra warmth rather than energy savings. Third, an upper level or maximum take-back temperature was achieved for the dwellings ranging from $20.85^{\circ} \mathrm{C}$ to $24.81^{\circ} \mathrm{C}$. Fourth, behavioural factors such as turning on the heating appear to be less relevant than physical factors such as energy-efficiency improvements to explain the increased of standardised mean internal air temperature. The study also suggests that local building characteristics (e.g. heating pipes routing) play an influential role and that to evaluate appropriateness of retrofitted energy-efficiency insulation measures pre-intervention variables such as internal temperatures, heating system and building fabric performance should be taken into account.
\end{abstract}

Keywords: buildings, energy, social housing, retrofit, temperature take-back

\section{Introduction}

This empirical study stemmed from a query raised by a social housing provider (Your Homes Newcastle -YHN-) to better understand the effects of building fabric retrofit on a deprived area. Social housing is defined as housing that is affordable, provided on a needsdriven basis where housing provision is not met by the market and includes households renting from Registered Providers, for example, a Local Authority or an Arms Length Management Organisations (ALMOs) such as YHN. The housing provider outlined their expectations such as a decrease in the heating bills, decrease full poverty, improve the property value and contribute with the regeneration of this area.

It is known that energy demand in social housing is affected by factors which are complex and often poorly understood [1]. Teli et al. [2], specifically, highlights the need to use empirical 
data as typical conditions representative of social homes could be far from those expressed in building energy models. Furthermore, empirical information on temperatures in domestic dwellings is valuable in appraising energy conservation interventions as, for example, the benefits of an energy efficiency intervention can be taken as energy consumption savings or extra warmth (i.e. required energy service) [3, 4] depending on household income level [5].

Building upon previous research propositions and findings, this investigation primary research proposition is that the reduction of energy consumption saving defined through temperature take-back exists and can be observed. In general, temperature take-back is defined as the change in mean internal temperatures following the building fabric retrofit and the reduction in energy consumption saving associated with that change. This means lower than expected gains of energy-efficiency improvements due to increased demand for energy services such as warmth[5]. Previous quantitative studies have shown that following retrofit predicted energy consumption savings are converted into increased internal temperatures [6, 4]. For example, a meta-review of 12 studies of household heating consumption concluded that the temperature take-back ranged from $0.14^{\circ} \mathrm{C}$ to $1.6^{\circ} \mathrm{C}$. This take-back is not insignificant as a " $1{ }^{\circ} \mathrm{C}$ increase in internal temperature may increase the energy consumption for space heating by $10 \%$ or more" [4, p. 26]. Furthermore, Sorrell [4] estimates that up to $100 \%$ of energy savings is lost through temperature take-back with a mean around $20 \%$.

Several studies have proposed that temperature take-back is higher in dwellings occupied by low-income householders [3, 4]. One suggested reason is that financial constraints on lowincome dwellings would lead to very low pre-intervention temperatures as these dwellings are often not warm enough for occupancy [3]. This means that low-income groups are more likely to have unmet demand for energy services (e.g. warmth -expressed as internal temperature), and, as a result of the unfulfilled demand, a higher temperature take-back. Other investigators have further suggested that it is likely that pre-retrofit internal temperature and low income are correlated [6] but few studies include measures of both. This study examines the association between temperature take-back and low-income dwellings.

Temperature take-back may also operate independently of socio economic characteristics. Sorrell [4] suggested that temperature take-back decreases owing to saturation effects when pre-intervention internal temperatures saturate (approaching $21^{\circ} \mathrm{C}$ ). This has been conceptualised as the saturation effect: the reduction in the level of service required (e.g. internal temperature) as the gap between that required service and thermal comfort level is reduced. The saturation effect implies that in a household where indoor temperatures approach the maximum level for thermal comfort adding more energy efficiency measures (e.g. wall insulation, double glazing) to the building's fabric and heating system will yield a negligible decrease in energy saving consumption in absolute terms. In this study, the Sorrel's saturation assumption is tested.

Finally, research studies have theorised that a part of the temperature take-back is accounted by the physical factors (e.g. building fabric retrofitted insulation and heating systems) and the remainder by the occupants behavioural change [7, 8]. Sorrell [4], for instance, stated that in household heating studies, building's physical characteristics accounted for nearly half of temperature take-backs and occupants' behavioural change for the reminder. This study probes the link between internal temperature and occupant behaviour.

Thus, on a UK high-rise social housing building, the empirical investigation presented in this paper interrogates: whether temperature take-back is taking place; whether temperature 
take-back is more prevalent on low-income households or operates independently due to saturation effects; and the relationship between temperature take-back, physical factors and occupant's behavioural change. The article is structured as follows: the methodology is first contextualised and introduced; the results are then presented; and they are explored further in the discussion section.

\section{Methodology}

\subsection{Approaches for estimating changes in energy demand following retrofit interventions}

In the UK, bottom-up physics-based modelling, also known as "engineering modelling", has been the foremost approach used for estimating potential savings from retrofit interventions. In the main, engineering studies explore the effect of retrofit insulation determining impact on energy consumption using heat transfer physical laws in steady state conditions to estimate changes on energy inputs. However, it has now been established that standard physics-based models overestimate the energy savings by possibly one half or more in lowincome households as stated by Sorrell et al. [6].

Predictive and adaptive thermal comfort models have also been used for understanding changes in energy service demand following retrofit. However, predictive models are not entirely suitable for the prediction of comfort in a domestic context as shown in the evidence presented by Hong et al. [9] and sufficient empirical data have not been collected for adaptive models to be applicable to residential buildings [10]

Due to the limitations in engineering and thermal comfort models to estimate energyefficiency intervention effects on energy demand, recent studies have followed the so called physical paradigm approach. Unlike the engineering approach, it is not based on theoretical models for estimating potential savings but on physical monitoring before and after building retrofit and does not predetermine occupant practices. In a fabric retrofit context, energy-efficiency intervention effects on energy demand can be measured in two categories: measuring the change in energy service or energy input [6]. Moreover, in this context, internal temperature is the preferred energy service demand variable to be observed [11] and taken as a pathway towards measuring temperature take-back in retrofit insulation studies [7]. This is because the energy service being demanded is a certain internal temperature during certain time periods through the day. As a result, an approach to calculating change in energy demand, termed quasi-experimental by Sorrell et al. [6], has emerged. The approach monitors physical variables (such as internal temperature and/or energy consumption), before and after, and goes on to compare the change to a counterfactual scenario. The counterfactual aims to estimate what demand would have been in the absence of the improvement [12] and whose value should be ideally obtained without the use of modelling to avoid, for example, reduction factor sources of uncertainty $[4,11]$. Recent investigations $[13,11,7]$ on the reduction of energy savings through temperature take-back have used a quasi-experimental approach to quantify the temperature take-back.

\subsection{An applied quasi-experimental and qualitative approach}

In this study a quasi-experimental approach has been coupled with qualitative methods and follow the so-called convergent research design rationale so that a more complete 


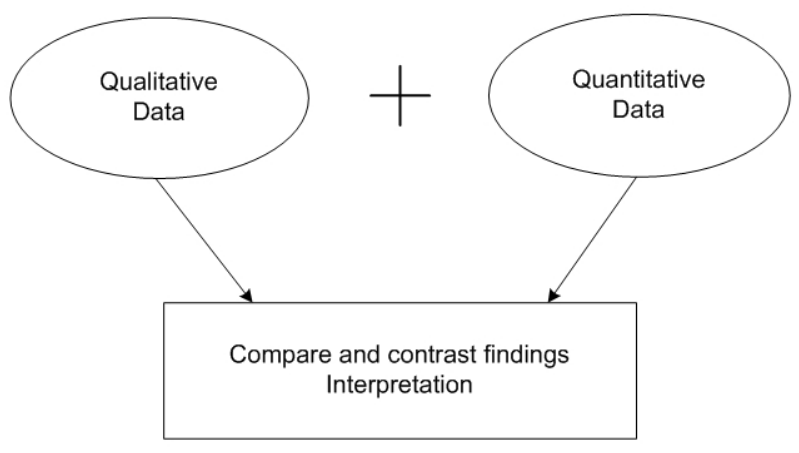

Figure 1: Convergent design [14].

understanding of the phenomena emerges [14] (e.g. everyday practices on space heating consumption and temperature take back [15]). Within this type of research design, quantitative and qualitative data are collected during the same time frames but stay separate as the findings of one phase are not subject to the results of the other (see Figures 1, 2).

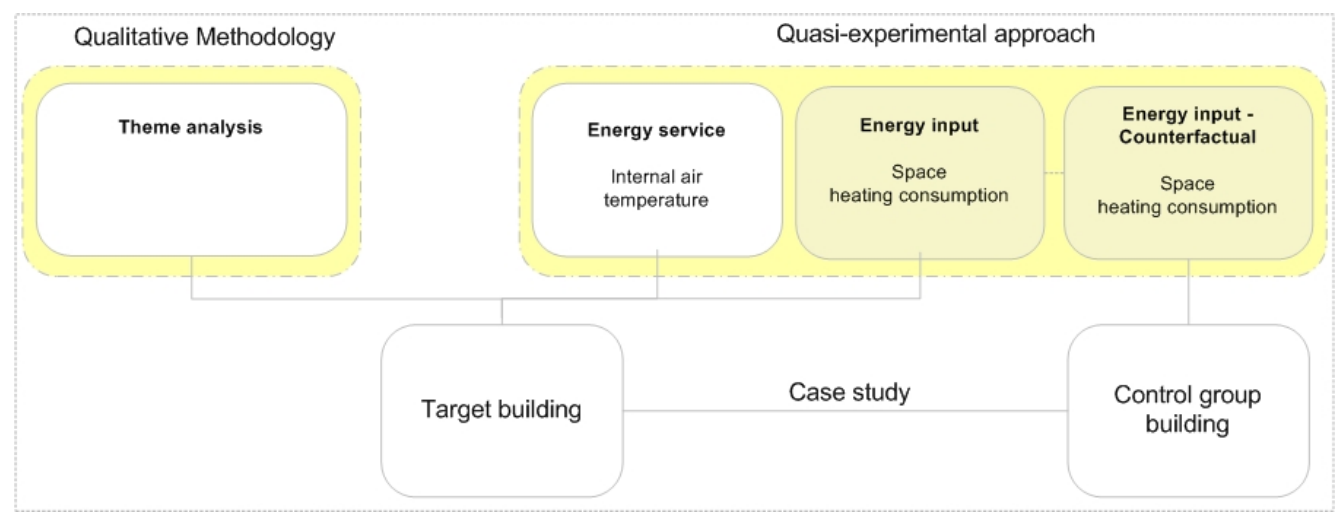

Figure 2: Quasi-experimental and qualitative methodology.

For the work in this paper, the applied quasi-experimental approach was designed for measuring change in internal air temperature (energy service) and space heating consumption (energy input) before and after retrofit as represented in Figure 3. The internal air temperature prior to retrofitting acts as a counterfactual scenario or an estimate for what "energy service" demand would have been without the improvement [6]. A counterfactual scenario for measuring the change in "energy inputs" was constructed using space heating consumption for a non-retrofitted-building control group over the same time period. A modelled counterfactual scenario was not introduced to limit uncertainties introduced with model predictions as described by Sorrell et al. [6] (see Figure 3).

Structured social demographic and thermal comfort questionnaires, and semi-structure interviews were the applied qualitative methods to study the population sample. A thematic analysis was carried to the semi-structured interviews' transcripts (see Figure 3).

The following paragraphs illustrate how the methodological approach was implemented. Firstly, a description of the building case study is provided. Secondly, an account of sample 
selection and data monitoring is presented followed by a description of the data analysis for the observed physical variables (i.e. internal air temperature as well as the space heating consumption counterfactual) and structured questionnaires and semi-structured interviews (see Figure 3). Finally, the approach limitations are described.

\subsubsection{Case study}

The study uses two high-rise social housing buildings located in the Riverside Dene Area in Newcastle upon Tyne, UK, managed by Your Home Newcastle (YHN): Cruddas Park House $(\mathrm{CPH})$ as the target building, and The Hawthorns as the control building. The target building is a 23- storey block with 157 flats and underwent to retrofit insulation (solid external wall insulation and double glazing windows) from September 2014 to February 2015 (Figure 4).

Socio demographics characteristics. The Riverside Dene project was originally a ten blocks scheme and a shopping centre built in the 1960's as part of a redevelopment programme [16]. Currently, only six tower blocks remain on the site as the rest were demolished before 2011. The majority of the occupants living in the Riverside Dene blocks have incomes that fall below the regional average (£13,329 per year) see Table 1 . Table 2 shows the dwellers demographic characteristics.

Table 1: Riverside Dene area income level. [17]

\begin{tabular}{ccc}
\hline $\begin{array}{c}\text { Total net income per annum } \\
(£)\end{array}$ & $\begin{array}{c}\text { Riverside Dene tenants } \\
\text { (number) }\end{array}$ & $\begin{array}{c}\text { Riverside Dene tenants } \\
(\%)\end{array}$ \\
\hline $0 \leq 5,199$ & 94 & 18 \\
$5,200 \leq 10,399$ & 260 & 50 \\
$10,400 \leq 15,599$ & 111 & 21 \\
$15,600 \leq 20,799$ & 40 & 8 \\
$\geq 20,800$ & 3 & 3 \\
\hline
\end{tabular}

Table 2: Riverside Dene area demographic data based on: Northgate (YHNs housing database) and ACORN (A Classification of Residential Neighbourhoods). ${ }^{*}$ The score indicates probability with 100 being a UK average. The higher the score the more likely; the lower the score the less likely. For example, the table shows that pensioners who live in the flats have a high likelihood (score of 310 ) to be retired as expected. ${ }^{* *}$ 65 years old.

\begin{tabular}{lccc}
\hline & UK average $^{*}$ & Pensionable age $^{* *}$ & Non-pensionable age \\
\hline Employment status & & & \\
Employed Full-Time (FT) & 100 & 22 & 110 \\
Employed Part-Time (PT) & 100 & 28 & 79 \\
Self-Employed (FT) & 100 & 22 & 77 \\
Self-Employed (PT) & 100 & 38 & 61 \\
Retired & 100 & 310 & 42 \\
Unemployed & 100 & 40 & 186 \\
\hline Education level & 100 & & 171 \\
Education (FT) & 100 & 274 & 92 \\
No formal qualifications & 100 & 62 & 101 \\
GCSE / O levels / CSE / School Certificate & 100 & 80 & 81 \\
ONC / BTEC / apprenticeship & 100 & 29 & 107 \\
A-levels / AS levels or Highers & 100 & 55 & 105 \\
Higher education below degree level & 100 & 24 & 117 \\
Degree or higher degree & & & \\
\hline
\end{tabular}




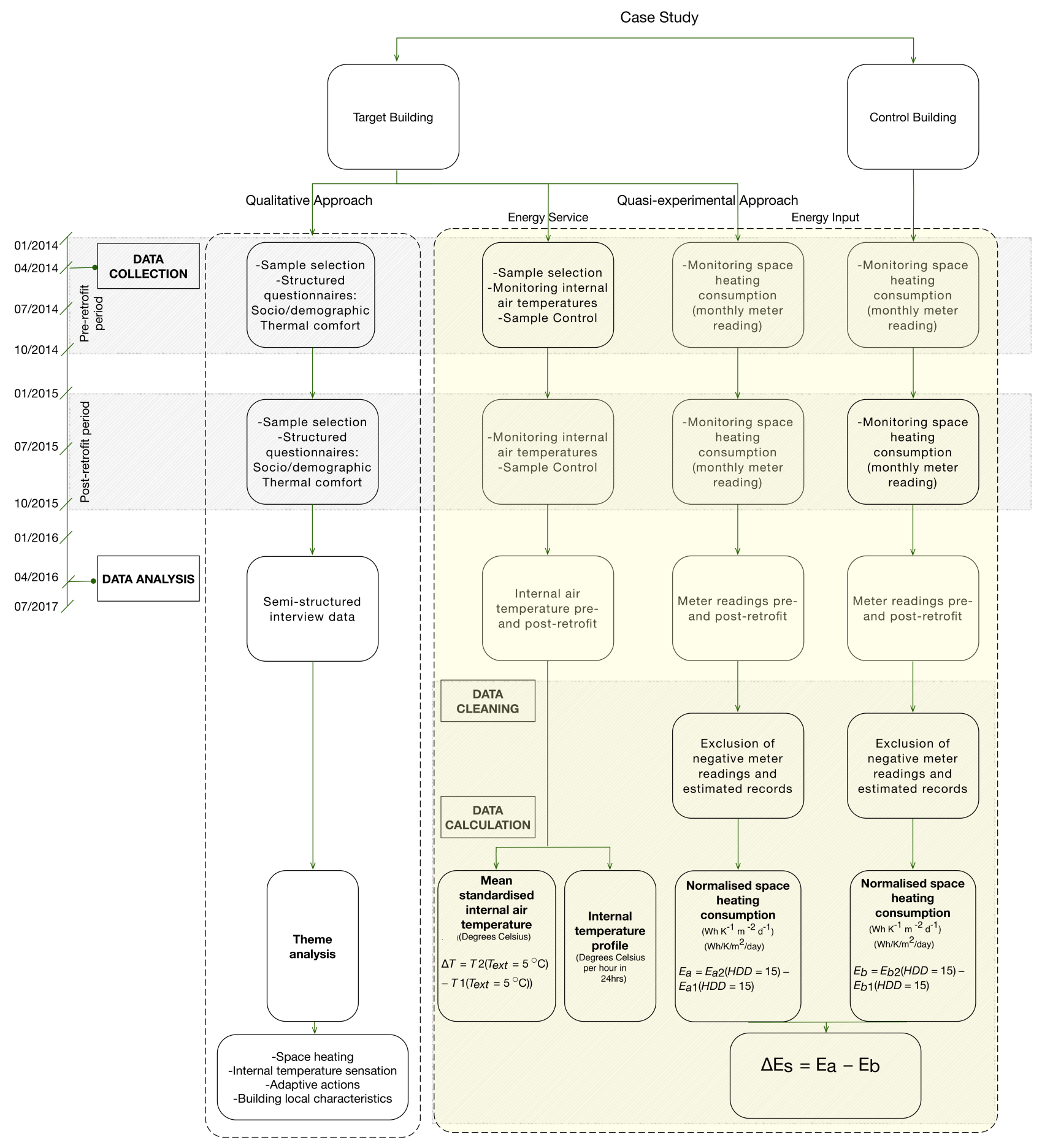

Figure 3: Applied quasi-experimental and qualitative methodological approach. See 2.2.3 for details on data calculation equations. 


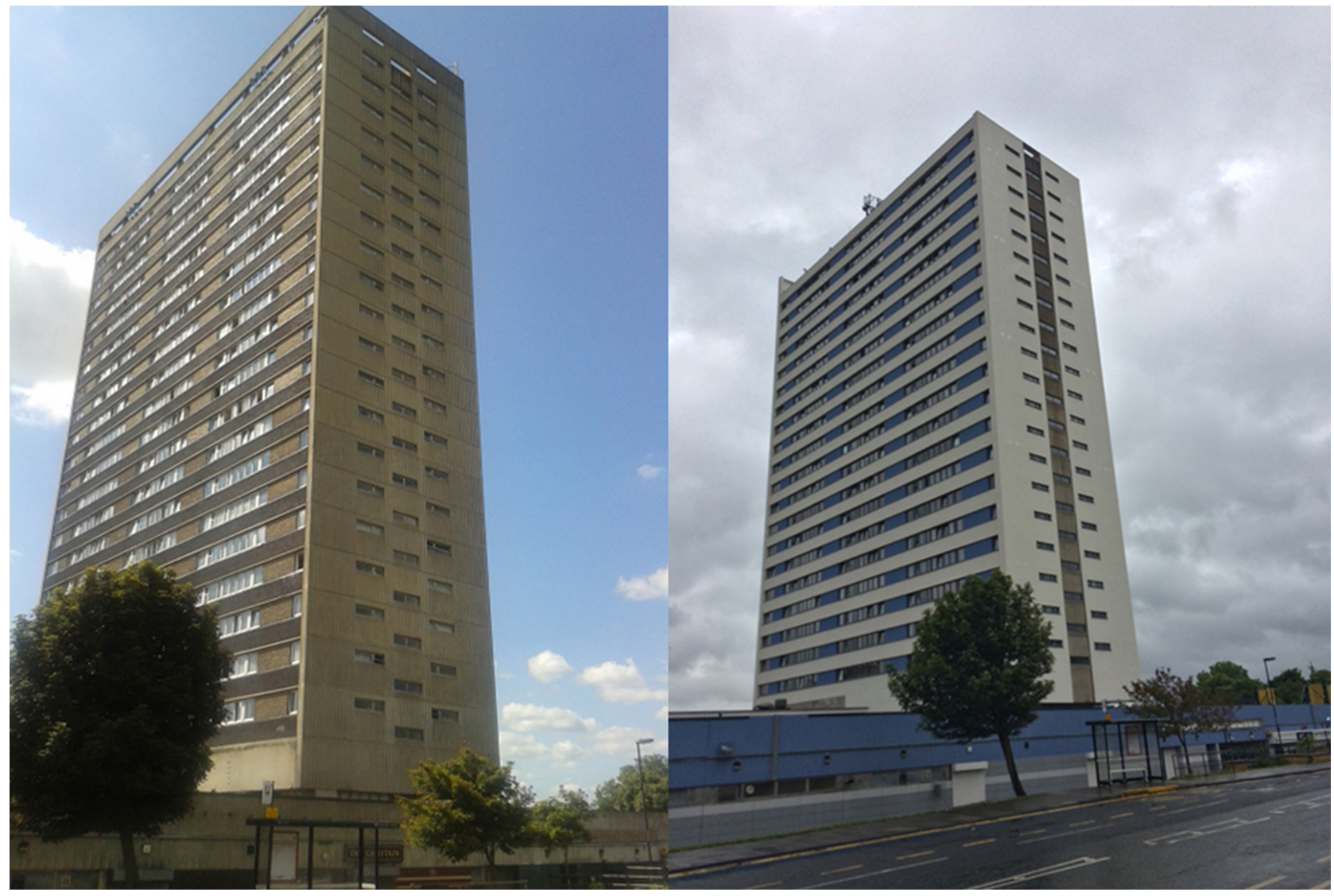

Figure 4: Left image, Cruddas Park House building (target building) before retrofit insulation (March 2014). Right image, Cruddas Park House building after retrofit insulation (March 2015). 
Buildings description. The target and the control buildings share similar physical building fabric characteristics and heating system. Ducted air stub ducts supply heat to the dwellings. Occupants interact with the heating system through an on/off button. Heat is measured at the individual dwelling level. Table 3 summarises the physical characteristics of both buildings.

For the retrofit the target building fabric was modified as follows: new external façade wall construction had insulation of $100 \mathrm{~mm}$ of HD mineral wool with a corresponding new U-value $0.28\left(\mathrm{~W} \mathrm{~m}^{-2} \mathrm{~K}^{-1}\right)$; and new double glazed windows with a corresponding U-value 1.7 $\left(\mathrm{W} \mathrm{m}^{-2} \mathrm{~K}^{-1}\right)$. The system used to upgrade the walls was an external insulation render system incorporating $100 \mathrm{~mm}$ of HD mineral wool insulation (nominal density $140 \mathrm{~kg} \mathrm{~m}^{-3}$ ). A base coat $(7 \mathrm{~mm})$ and reinforcing mesh were also applied along with a top coat of silicon-resin of $1.5 \mathrm{~mm}$. The windows were upgraded with 28- $\mathrm{mm}$ air-filled double-glazed units, which have $4 \mathrm{~mm}$ of inner pane, $20 \mathrm{~mm}$ air space between the panes and $4 \mathrm{~mm}$ outer pane. The window energy rating (WER) specified were band C. Neither the air tightness was addressed nor anything was done to the heating system and controls as part of the retrofit project. Both buildings have same gas tariffs, each flat has a gas meter for hot water and a gas meter for space heating consumption. The information recorded in both meters is used for billing purposes and it is automatic transmitted every month to a central database.

Table 3: Target and control building fabric physical characteristics. * Before upgrade. ${ }^{* *}$ Variable wall-u value is due to uneven construction in the original façade. ${ }^{* * *}$ In relation to true North. ${ }^{* * * *}[18]$.

\begin{tabular}{|c|c|c|}
\hline & Target Building & Control Building \\
\hline Building use & Residential & Residential \\
\hline Construction year & $1960 \mathrm{~s}$ & $1960 \mathrm{~s}$ \\
\hline Number of stories & 23 & 15 \\
\hline Number of dwelling units & 157 & 76 \\
\hline Number of bedrooms & 1 or 2 & 1 or 2 \\
\hline Average flat floor area $\left(\mathrm{m}^{2}\right)$ & 70 & 59 \\
\hline Energy efficiency rating & 76 points $($ Band $\mathrm{C}) *$ & 83 points (Band B) \\
\hline Wall construction & Precast concrete frame with concrete infill panel & Precast concrete frame with concrete infill panel \\
\hline Wall U-value $\left(\mathrm{Wm}^{-2} \mathrm{~K}^{-1}\right)$ & $0.53-0.89^{* * *}$ & 0.30 \\
\hline Window U-value $\left(\mathrm{W} \mathrm{m}^{-2} \mathrm{~K}^{-1}\right)$ & $4.3^{*}$ & 1.7 \\
\hline Orientation $^{* * *}$ & $10^{\circ} \mathrm{E}$ & $10^{\circ} \mathrm{W}$ \\
\hline Heating system ${ }^{* * * *}$ & $\begin{array}{r}\text { Primary source: } 750 \mathrm{~kW} \\
\text { For peak demand periods: one } 1.5 \mathrm{MW} \text { gas fired }\end{array}$ & $\begin{array}{l}\text { ss community heating system } \\
\text { and two existing } 1.2 \mathrm{MW} \text { gas boilers act as back-up }\end{array}$ \\
\hline
\end{tabular}

\subsubsection{Data collection}

Implementation of data collection was divided into three stages: 1) sample selection; 2) monitoring internal air temperatures, and space heating consumption; and 3) structured questionnaires and semi-structured interviews. See overview in Figure 3.

\section{Sample selection}

A convenience sample was employed which is subject to self-selection as all residents of the target building were invited to participate. Recruited volunteers were required to have occupied the building for at least one year prior to the building being upgraded (in order to have historical energy heating records), to complete a one-year study, and to agree to the installation of a data logger. As recruiting participants amongst vulnerable communities is challenging, the study's strategy focused in gaining the trust of residents using different techniques: letters, posters located at the building, drop-in sessions and knocking on doors. The idea that residents were involved in a research study design to understand the impact of 
the proposed retrofit was well received and aided with participant recruitment. Thus, from the target building, 25 volunteers agreed to participate of which only 15 met the recruitment criteria, and 9 completed the study or $7 \%$ of the occupied flats (see Table 4).

Table 4: Selected participants

\begin{tabular}{ccccc}
\hline $\begin{array}{c}\text { Participant } \\
\text { / Flat }\end{array}$ & Tenure & Gender & $\begin{array}{c}\text { Age band } \\
\text { (years) }\end{array}$ & $\begin{array}{c}\text { Occupants } \\
\text { (number) }\end{array}$ \\
\hline 1 & rented & male & $51-60$ & 1 \\
2 & rented & female & $51-60$ & 1 \\
3 & rented & male & $51-60$ & 1 \\
4 & rented & female & $61-70$ & 1 \\
5 & rented & male & $61-70$ & 1 \\
6 & rented & male & $71-80$ & 1 \\
7 & rented & male & $51-60$ & 1 \\
8 & rented & female & $51-60$ & 1 \\
9 & rented & male & $61-70$ & 1 \\
\hline
\end{tabular}

\section{Monitoring internal air temperatures and space heating consumption}

Internal air temperatures.

Temperatures were monitored at 30 minute intervals before and after retrofit, by placing data loggers in the participant's living room (see Figure 5). Gemini TinyTag data loggers (see Section 6 Table 14) were used and located away from direct sources of heat and light on as suggested by ISO 7726:2001 ([19]). Indoor temperatures are strongly influenced by external meteorological conditions. Thus, external temperatures were collected using a Gemini data logger (see Section 6, Table 14) which was installed on the roof of the target building (the closest place to the flats due to the external wall retrofit) to monitor external temperature at 30 minutes intervals. Whilst the total building height was $75 \mathrm{~m}$, the monitored flats were on average $25 \mathrm{~m}$ below the data logger. Using NASA's AtmosModeler [20] rate of change of temperature, this equates to a maximum of $0.175^{\circ} \mathrm{C}$ difference.

Space heating consumption.

A dataset of monthly gas consumption from each flat in the target building (157 flats) and control group (76 flats) was provided by the housing association covering the period before and after the retrofit. The dataset contained hot water meter readings in cubic meters $\left(\mathrm{m}^{3}\right)$ and space heating meter readings in kilowatt-hours $(\mathrm{kWh})$. This information was provided in an anonymised file under a non-disclosure agreement. In addition, monthly electricity meter readings were also collected from each participant's dwelling, before and after retrofit insulation.

\section{Structured questionnaires and semi-structured interviews}

Structured questionnaires and semi-structured interviews were used for briefing, debriefing purposes, and capturing change in the individual households circumstances during the retrofit process (e.g. change of employment status) and identifying the ownership and use of other heater during the retrofit process. In addition, socio-demographic structured questionnaires were used to identify the demographic profile of the respondent household to characterise the population at the target building (i.e. family size, gender, age, household composition, occupation and education); structured questionnaires were also used to collect 

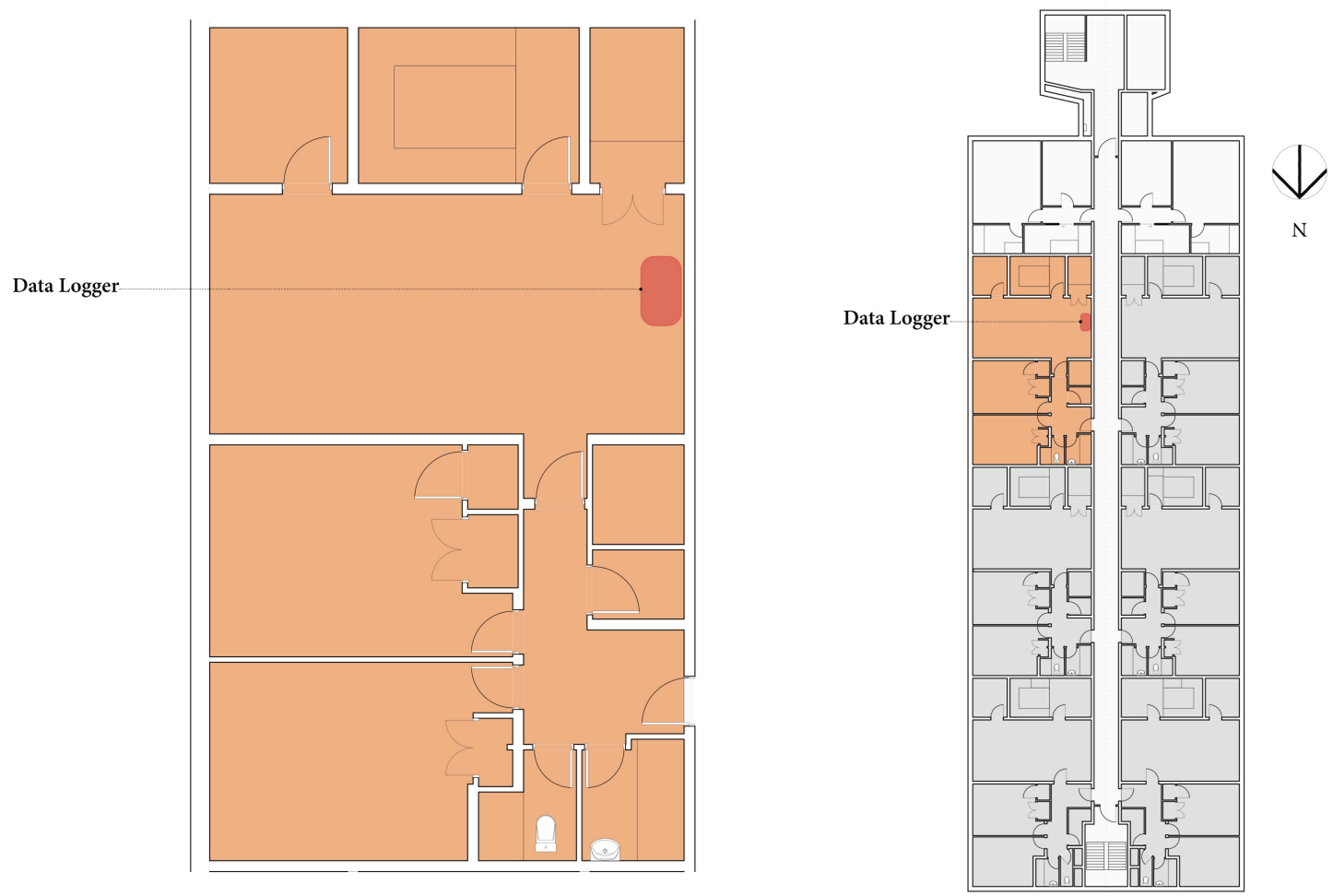

Figure 5: Target building floor plan and data logger location.

thermal comfort and external appearance perception data pre- and post-retrofit. Both questionnaires used 5 -point Likert scale (for example $1=$ very cold, $2=$ cold, $3=$ neutral, $4=$ warm, $5=$ very warm for thermal comfort perception).

A semi-structured interview was carried out at the end of the study around themes such as use of heating (main heating and secondary heating. See section 3.3.1); thermal comfort perception - how cold or warm do they feel at their flat-; and ventilation and infiltration questions. These interviews were audio recorded with the permission of the participants.

\subsubsection{Data analysis}

A total of 1398 meter readings data (456 control group and 942 target group) were analysed from a total of 233 flats. The first step in the analysis was to clean the space heating meter readings records by removing potentially erroneous data points (i.e negative values and estimated records) to calculate weather normalised space heating consumption change in the control and target buildings.

\section{Mean standardised internal air temperature calculation}

This metric compares changes before and after retrofit using monitored data and follows Oreszczyn et al. [7] and Love [11] so as to ensure annual comparisons and compatibility with other studies. Standardisation makes internal air temperatures independent of external meteorological conditions [7]. This study has standardised mean internal air temperature to a fixed external temperature of $5{ }^{\circ} \mathrm{C}$ by following four steps:

First, days with mean external temperatures above $15^{\circ} \mathrm{C}$ were excluded to improve the 
prediction of mean internal air temperature in the heating season as heating would normally be switched off due to incidental heat gains providing adequate heating [7]. Second, the mean internal air temperature was calculated daily and two linear regressions between mean internal and mean external temperatures were carried out, one pre-retrofit and other post retrofit. Third, a $5{ }^{\circ} \mathrm{C}$ single external temperature was selected so as to derive the mean standardised internal air temperature for the target building pre-retrofit ( $\mathrm{T} 1$ ) and postretrofit (T2) using the calculated linear regressions. Finally, the metric is calculated as per equation 1 . Where, $\Delta T$ is the difference in mean internal air temperature under standardised conditions; $\mathrm{T} 1$ is the standardised mean internal air temperature $\left({ }^{\circ} \mathrm{C}\right)$ for pre-retrofit; and $\mathrm{T} 2$ is the standardised mean internal air temperature $\left({ }^{\circ} \mathrm{C}\right)$ for post-retrofit.

$$
\left.\Delta T=T 2\left(T_{e x t}=5{ }^{\circ} \mathrm{C}\right)-T 1\left(T_{e x t}=5^{\circ} \mathrm{C}\right)\right)
$$

\section{Profile temperature calculation}

The profile temperature was constructed by plotting the daily mean internal air temperatures $\left({ }^{\circ} \mathrm{C}\right)$ so as to observe changes in 24 hours heating periods. The derived plotted graphs show hourly mean internal air temperatures values from different days during the monitoring period. A trend curve was also plotted on the profile temperature graphs, before and after the upgrade so as to compare them to the BREDEM-12 internal temperature profile [21]. See Figure 11.

Weather-normalised space heating consumption calculation

The metric change in weather normalised space heating consumption was constructed following other studies (e.g. [22]) so as to account for the influence of external temperatures on space heating consumption and to provide a means of comparing the consumption before and after the upgrade. Similarly, space heating consumption was normalised for the variation between indoor and outdoor temperature (heating degrees days) and dwelling size [22]. Heating degree days (HDD) are calculated- "by summing the temperature difference between the daily mean internal base temperature and the daily mean external temperature " $[22, \mathrm{p}$. 1173]. The daily mean internal base temperature was set up to the number of days that the mean outdoor temperature was equal to or below $15^{\circ} \mathrm{C}$.

The normalized heating consumption for the target building $\left(E_{a}\right)$ and control building $\left(E_{b}\right)$ is defined by equations 2 and 3 . Where $E_{a 1}, E_{b 1}$ indicates pre-retrofit and $E_{a 2}, E_{b 2}$ post-retrofit.

$$
\begin{aligned}
& E_{a}=E_{a 2}(H D D=15)-E_{a 1}(H D D=15) \\
& E_{b}=E_{b 2}(H D D=15)-E_{b 1}(H D D=15)
\end{aligned}
$$

The change of space heating consumption following retrofit is calculated through the difference in space heating consumption under normalised weather conditions (see equation 4). Where $\Delta E_{s}$ is the difference in space heating consumption under normalized weather conditions for the buildings under study (target(a) and control(b)) $\left(\mathrm{Wh} \mathrm{K}^{-1} \mathrm{~m}^{-2} \mathrm{~d}^{-1}\right) ; E_{a}$ weather-normalised space heating consumption for the target building $\left(\mathrm{W} \mathrm{h} \mathrm{K}^{-1} \mathrm{~m}^{-2} \mathrm{~d}^{-1}\right) ; E_{b}$ weather-normalised space heating consumption for the control building $\left(\mathrm{Wh} \mathrm{K}^{-1} \mathrm{~m}^{-2} \mathrm{~d}^{-1}\right)$. 


$$
\Delta E_{s}=E_{a}-E_{b}
$$

\section{Thematics}

The analysis method of emergent themes from the interview data was developed throughout an iterative coding process in order to capture key data that enables the identification of patterns [23]. Firstly, the analysis method began generating codes with every sentence, for example the researcher identified the following codes under potential subthemes: opening the windows, use of fan, ventilation corridor, health issues (related temperatures), concerns (related temperatures) and change in dressing practices. Secondly, the analysis method explored connections between these themes in relation to the entire data set. The themes were linked and superimposed to form a broad theme(s) from this analysis. For example, adaptive practices emerged as an important theme. The results were used in descriptive and interpretative ways for triangulation with the mean internal air temperature and space heating consumption analysis. This led to provide a more comprehensive account of internal temperature and space heating consumption changes -completeness- and to illustrate why these changes to the physical variables might be taken place.

\subsubsection{Methodological design challenges}

Quasi-experimental methods have proven to be useful $[22,7]$. They can be applied to larger scale longitudinal studies with well designed counterfactuals [4] and comprehensive monitoring set ups of physical building and occupant variables. This is, however, a challenging task as they have known theoretical and practical design challenges [6]. First, exogenous factors (which may modify the demand of energy service) and confounding variables (which ensure scope and validity of the counterfactual) need to be fully controlled [4]. This study addressed the exogenous factors imposing the exogeneity [24] to control conditions such as the type of retrofit insulation, building physical characteristics, energy tariff, and energy supplier. However, future studies should control further exogenous factors, in particular, those related to occupants interactions with the building physical and heating system such as window opening. Second, quasi-experimental studies are subject to selection bias [25]. Normally, a full sample size will not be attainable so a criteria for sample selection will be needed. In this project, occupants' disposition to installing a data logger in their flat and participating in a 2 year study were the determining criteria. Third, a suitable spatial and data capture monitoring set-up of the representative energy service demand variables is needed. In this study, it was achieved by one internal air temperature logger in the living room and monthly space heating consumption data. This was based on the assumption that occupants in small dwellings perceive their place as one space [26] and the SAP (Standard Assessment Procedure) assumption that the living room is the warmest location in a dwelling [27]. Further studies might be able to improve both spatial and data capture monitoring set-up by including bedrooms for instance. Finally, in this study, coupling quantitative and qualitative methods has enabled to further capture physical and occupant interactions but, for future studies, this coupling might be extended whilst ensuring findings divergence [14] does not occur. 


\section{Results}

In this section, the results related to internal temperatures and space heating consumption are presented.

\subsection{Internal Temperatures}

\subsubsection{Mean standardised internal air temperature}

Figure 6 shows mean internal air temperatures at different external temperatures before and after retrofit. Figure 6 also shows that the mean standardised internal air temperature ranged from $22.07^{\circ} \mathrm{C}$ to $22.53^{\circ} \mathrm{C}$ for the sample ( 9 dwellings): $+0.46{ }^{\circ} \mathrm{C}$ or $2 \%$ higher than before the upgrade.

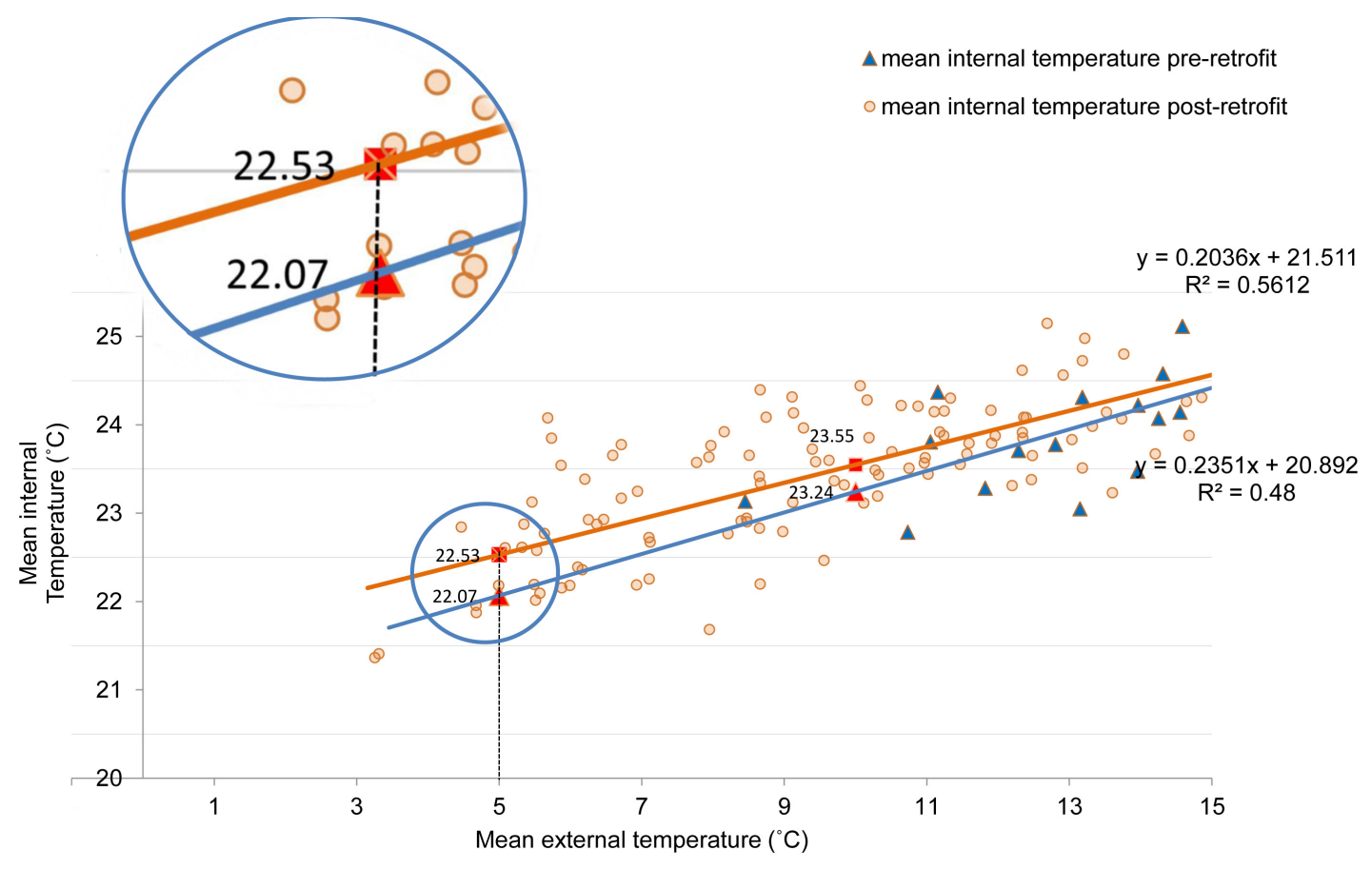

Figure 6: Standardised mean internal air temperature of the target building, at $5.0^{\circ} \mathrm{C}$ external temperature. Pre- and post-retrofit $(\mathrm{n}=9)$.

Figure 7 and Figure 8 illustrate the results from a regression analysis to determine the relationship between mean internal air temperatures and mean external air temperatures per dwelling (9 flats) before and after retrofit. Specifically, Figures 7b, 7c, 7d, 8b, and 8e show an increase of the mean standardised internal air temperature in each dwelling. At $5{ }^{\circ} \mathrm{C}$ external temperature, this increase in temperature ranged from a $+4.80^{\circ} \mathrm{C}$ or $26.68 \%$ in Flat $2\left(17.99^{\circ} \mathrm{C}\right.$ to $22.79^{\circ} \mathrm{C}$ see Figure $\left.7 b\right)$ to a $+0.33^{\circ} \mathrm{C}$ or $1.56 \%$ in Flat $9\left(21.13^{\circ} \mathrm{C}\right.$ to $21.46^{\circ} \mathrm{C}$ see Figure 8e). On the other hand, Figures $7 \mathrm{a}, 8 \mathrm{a}, 8 \mathrm{c}$, and $8 \mathrm{~d}$ show a decrease of the mean standardised internal air temperature in each dwelling. This decrease in temperature ranges from a $-2.66^{\circ} \mathrm{C}$ or $-11.70 \%$ in Flat $1\left(22.74{ }^{\circ} \mathrm{C}\right.$ to $20.08^{\circ} \mathrm{C}$ see Figure 7 a $)$ to a $-1.26^{\circ} \mathrm{C}$ or $-5.57 \%$ in Flat $5\left(22.63^{\circ} \mathrm{C}\right.$ to $21.37^{\circ} \mathrm{C}$ see Figure $\left.8 \mathrm{a}\right)$. 


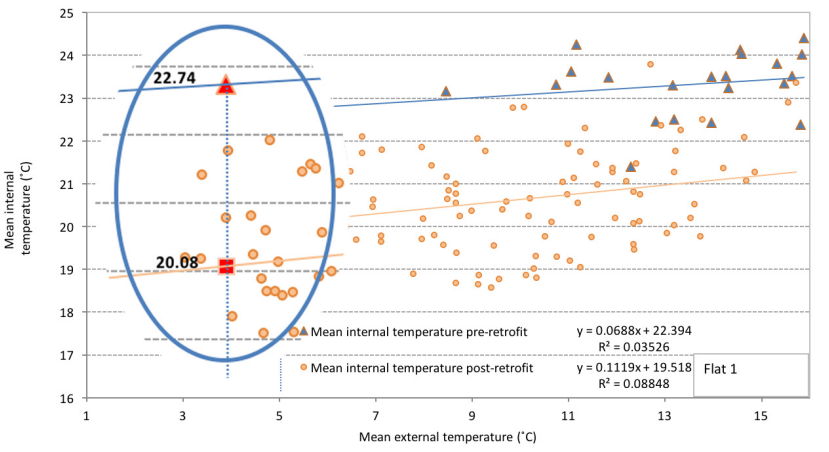

(a) Flat 1

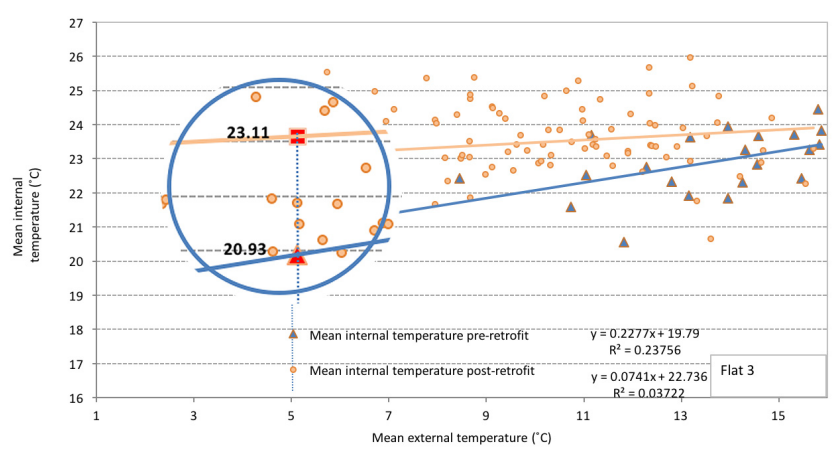

(c) Flat 3

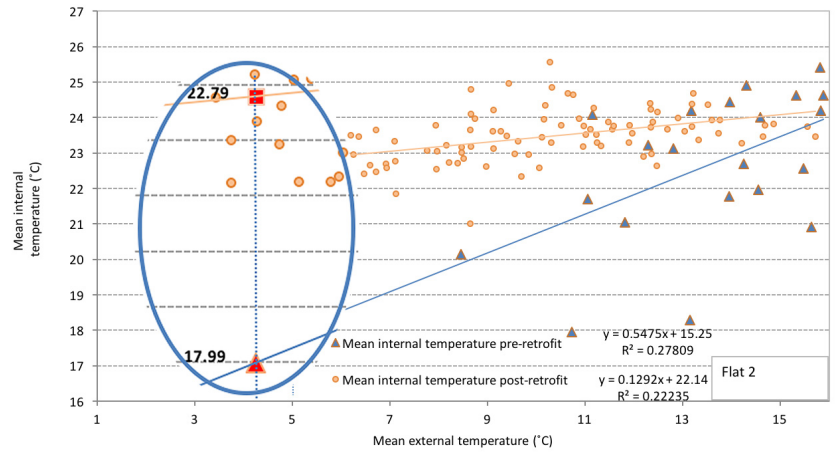

(b) Flat 2

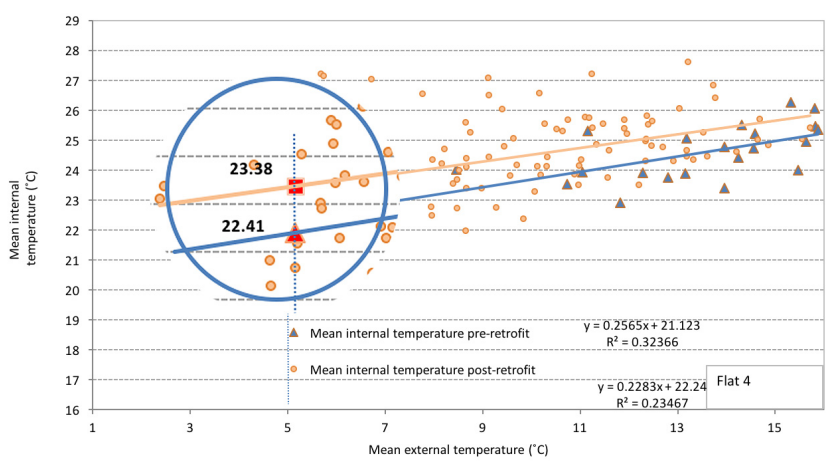

(d) Flat 4

Figure 7: Standardised mean internal air temperature of the target building, at $5.0^{\circ} \mathrm{C}$ external temperature. Pre- and post-retrofit per individual flat. 


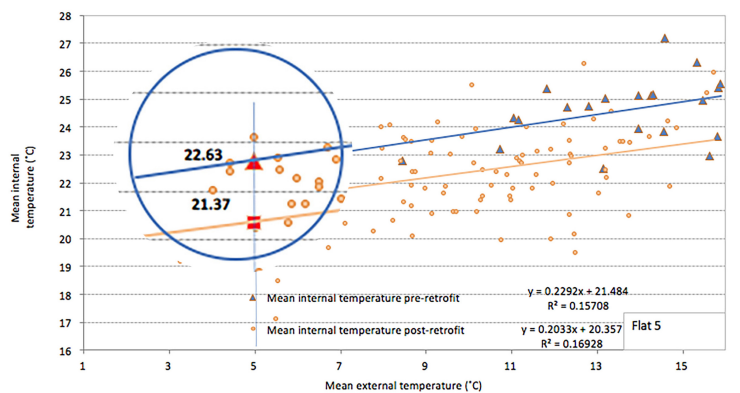

(a) Flat 5

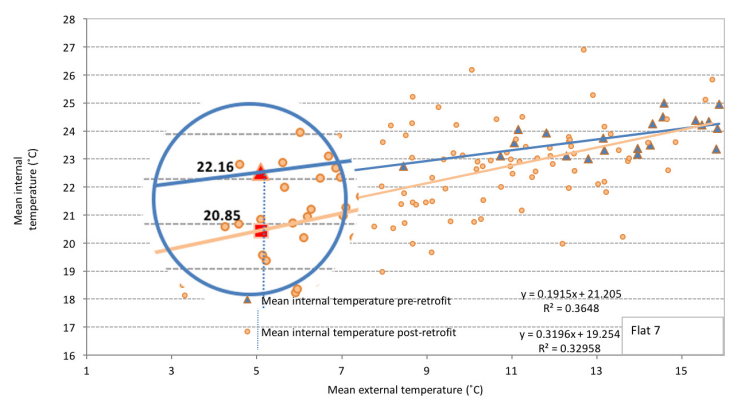

(c) Flat 7

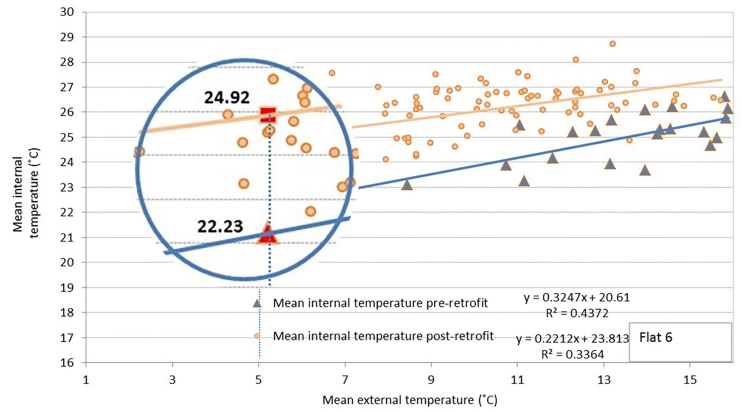

(b) Flat 6

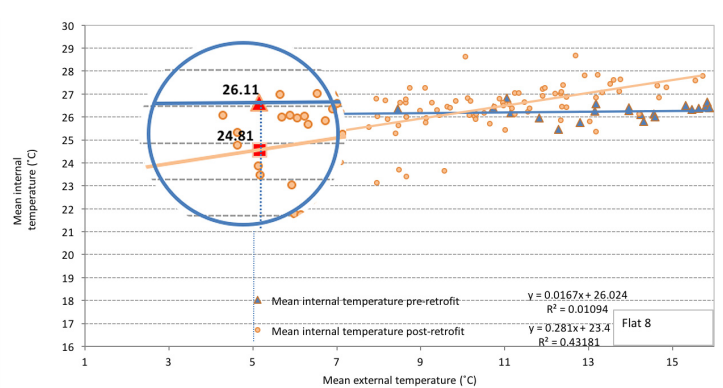

(d) Flat 8

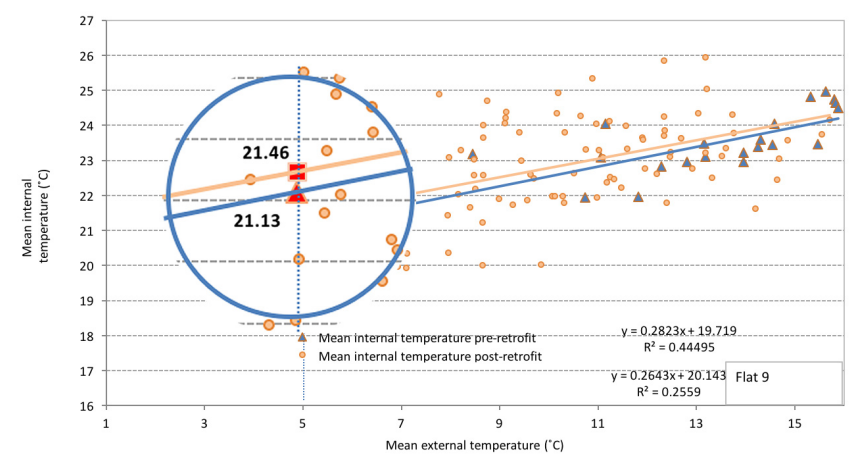

(e) Flat 9

Figure 8: Standardised mean internal air temperature of the target building, at $5.0^{\circ} \mathrm{C}$ external temperature. Pre- and post-retrofit per individual flat. 


\subsubsection{Internal temperature profile}

Figure 9 and Figure 10 illustrate the observed non-standardised mean internal air temperature profile within a day pre- and post-retrofit respectively. Figure 9 and Figure 10 are represented by a fourth-order polynomial and show that non-standardised mean internal air temperature profiles pre- and post-retrofit are similar and that the maximum temperature difference within a day is negligible. For example, pre-retrofit there is a small difference of less than $1.0^{\circ} \mathrm{C}$ between $23.7^{\circ} \mathrm{C}$ and $24.5^{\circ} \mathrm{C}$ within a day. Post-retrofit there is also a small difference from $22.8^{\circ} \mathrm{C}$ to $24.00^{\circ} \mathrm{C}\left(1.2^{\circ} \mathrm{C}\right)$. These small maximum temperature differences pre- and post-retrofit suggest that before and after retrofit dwellings have a quasi-flat internal air temperature profile.

At an individual dwelling level, Figure 12 and Figure 13 illustrate the distinct temperature profile per dwelling (9 flats) surveyed in the case study before and after retrofit.

Specifically, Figures 12c, 12d, 13b and 13d show that the pre-retrofit and post-retrofit internal temperature profile could be regarded as quasi-flat profile. Typically, for this study, a flat which conforms to this profile is characterised by the absence of heating periods and small internal air temperature range (i.e.difference between maximum and minimum temperature less or equal to $1.5^{\circ} \mathrm{C}$ ). Table 5 describes the internal temperature profiles for dwellings $3,4,6$, and 8 . Thus, these pre and post retrofit quasi-flat temperature profiles denote the absence of occupant-controlled heating periods.

Table 5: Internal temperature profile description dwellings $3,4,6$, and 8.

\begin{tabular}{|c|c|}
\hline Dwelling & Internal temperature profile description \\
\hline 3 (Figure 12c) & $\begin{array}{l}\text { Pre-retrofit. A quasi-flat profile with a range of } 1.2^{\circ} \mathrm{C} \text { in which the mean internal air temperature was } 23.0^{\circ} \mathrm{C} \\
\text { with a morning maximum of } 23.4^{\circ} \mathrm{C} \text { at } 5: 00 \text { and a night maximum of } 23.4^{\circ} \mathrm{C} \text { at } 24: 00 \\
\text { Post-retrofit. A quasi-flat with a range of } 0.4{ }^{\circ} \mathrm{C} \text { in which the mean internal air temperature was } 23.5^{\circ} \mathrm{C} \\
\text { with a morning maximum of } 23.6^{\circ} \mathrm{C} \text { at } 6: 00 \text { and an evening maximum of } 23.7^{\circ} \mathrm{C} \text { at } 19: 00\end{array}$ \\
\hline 4 (Figure 12d) & $\begin{array}{l}\text { Pre-retrofit. A quasi-flat profile with a range of } 1.0^{\circ} \mathrm{C} \text { in which the mean internal air temperature was } 25.0^{\circ} \mathrm{C} \\
\text { with a morning maximum of } 24.9^{\circ} \mathrm{C} \text { at } 7: 00 \\
\text { Post-retrofit. A quasi-flat with a range of } 1.0^{\circ} \mathrm{C} \text { in which the mean internal air temperature was } 24.4^{\circ} \mathrm{C} \\
\text { with a morning maximum of } 24.8^{\circ} \mathrm{C} \text { at } 9: 00\end{array}$ \\
\hline 6 (Figure 13b) & $\begin{array}{l}\text { Pre-retrofit. A quasi-flat profile with a range of } 1.4^{\circ} \mathrm{C} \text { in which the mean internal air temperature was } 25.0^{\circ} \mathrm{C} \\
\text { with a morning maximum of } 25.8^{\circ} \mathrm{C} \text { at } 6: 00 \\
\text { Post-retrofit. A quasi-flat profile with a range of } 0.7^{\circ} \mathrm{C} \text { in which the mean internal air temperature was } 26.0^{\circ} \mathrm{C} \\
\text { with a morning maximum of } 26.3^{\circ} \mathrm{C} \text { at } 8: 00\end{array}$ \\
\hline 8 (Figure 13d) & $\begin{array}{l}\text { Pre-retrofit. A range of } 1.0^{\circ} \mathrm{C} \text { in which the mean internal air temperature was } 26.0^{\circ} \mathrm{C} \\
\text { with an afternoon maximum of } 26.8^{\circ} \mathrm{C} \text { at } 17: 00 \\
\text { Post-retrofit. A quasi-flat profile with a range of } 0.2^{\circ} \mathrm{C} \text { in which the mean internal air temperature was } 26.0^{\circ} \mathrm{C} \\
\text { with an evening maximum of } 26.2^{\circ} \mathrm{C} \text { at } 20: 00\end{array}$ \\
\hline
\end{tabular}

Figures 12a, 12b, and 13c, on the other hand, illustrate that flat 1, 2 and 7 had a quasi-flat pre-retrofit temperature profile but a 1 heating period post-retrofit temperature profile. That is, a post-retrofit temperature profile with a pattern of temperature increase, with one heating period in the morning or in the afternoon. Table 6 describes the internal temperature profiles for dwellings 1,2 and 7 .

A 1 heating period pre and post-retrofit temperature profile. Figure 13a and Figure 13e may denote an occupant-controlled heating period or an expected rise of internal temperature due to the flat local conditions within the building whereas post-retrofit temperature profile denotes heating periods. Table 7 describes the internal temperature profiles for dwellings 5 and 9. 
Table 6: Internal temperature profile description dwellings 1, 2 and 7.

\begin{tabular}{|c|c|}
\hline Dwelling & Internal temperature profile description \\
\hline 1 (Figure 12a) & $\begin{array}{l}\text { Pre-retrofit. A quasi flat pre-retrofit temperature profile with a range of } 0.8^{\circ} \mathrm{C} \text { in which the mean internal air temperature was } 23.0^{\circ} \mathrm{C} \\
\text { with an evening maximum of } 23.8^{\circ} \mathrm{C} \text { at } 18: 30 \\
\text { Post-retrofit. A quasi linear increase from } 7: 00 \text { which reaches a maximum of } 21.4^{\circ} \mathrm{C} \text { at } 18: 00 . \\
\text { This is followed by a quasi linear decline of } 1.5^{\circ} \mathrm{C} \text { till } 6: 00\end{array}$ \\
\hline 2 (Figure 12b) & $\begin{array}{l}\text { Pre-retrofit. a quasi flat pre-retrofit temperature profile with a range of } 0.7^{\circ} \mathrm{C} \text { in which the mean internal air temperature was } 23.0^{\circ} \mathrm{C} \\
\text { with a morning maximum of } 23.1^{\circ} \mathrm{C} \text { at } 8: 30 \\
\text { Post-retrofit. A gradual increase from } 7: 00 \text { reaching a maximum of } 24.5^{\circ} \mathrm{C} \text { at } 9: 00 \text { followed by gradual temperature decrease of } 1.3^{\circ} \mathrm{C} \text { until } 17: 00 \text {. } \\
\text { After that, there is slight increase of } 0.3^{\circ} \mathrm{C} \text { till } 24: 00 \text { followed by a decrease of } 1.8^{\circ} \mathrm{C} \text { till } 6: 00\end{array}$ \\
\hline 7 (Figure 13c) & $\begin{array}{l}\text { Pre-retrofit. A quasi flat pre-retrofit temperature profile with a range of } 1.4^{\circ} \mathrm{C} \text { in which the mean internal air temperature was } 24.0^{\circ} \mathrm{C} \\
\text { with an evening maximum of } 24.5^{\circ} \mathrm{C} \text { at } 17: 00 \\
\text { Post-retrofit. A quasi linear increase from } 8: 00 \text { which reaches a maximum of } 23.49^{\circ} \mathrm{C} \text { at } 17: 00 . \\
\text { This is followed by a quasi linear decline of } 1.5^{\circ} \mathrm{C} \text { till } 7: 00\end{array}$ \\
\hline
\end{tabular}

Table 7: Internal temperature profile description dwellings 5 and 9.

\begin{tabular}{|c|c|}
\hline Dwelling & Internal temperature profile description \\
\hline \multirow{5}{*}{5 (Figure 13a) } & Pre-retrofit. There is an increase of temperature from $7: 00$ which reaches a maximum of $26.0^{\circ} \mathrm{C}$ at $17: 30$. \\
\hline & The temperature gradient changes at 15:00. This is followed by a quasi linear decline of $2.6^{\circ} \mathrm{C}$ till $7: 00$ \\
\hline & Post-retrofit. There is an increase of temperature from 7:00 which reaches a morning "peak" of $21.9^{\circ} \mathrm{C}$ at $9: 00$ and then declines until $11: 00$ by $0.4^{\circ} \mathrm{C}$. \\
\hline & From 11:00 till 16:00, there is a continuous increased of temperature of $3.7^{\circ} \mathrm{C}$, reaching a maximum of $25.2^{\circ} \mathrm{C}$ \\
\hline & ich is followed by an overall decline of $4.7^{\circ} \mathrm{C}$ between $16: 00$ and 7:00. \\
\hline \multirow{4}{*}{9 (Figure 13e) } & In this decline there are two different temperature gradients one at $16: 30$ and the other at $21: 30$ \\
\hline & Pre-retrofit. There is a gradual increase of temperature from $6: 00$ which reaches a maximum of $24.4^{\circ} \mathrm{C}$ at 8:00. \\
\hline & Post-retrofit Smoother mornino profile which reaches a morning maximum of $233^{\circ} \mathrm{C}$ at \\
\hline & $\begin{array}{l}\text { Post-retrofit. Smoother morning profle which reaches a morning maximum of } 23.3^{\circ} \mathrm{C} \text { at } \\
\text { Then a gradual decline from } 12: 00 \text { till } 6: 00 \text { of } 1.6^{\circ} \mathrm{C} \text {. }\end{array}$ \\
\hline
\end{tabular}

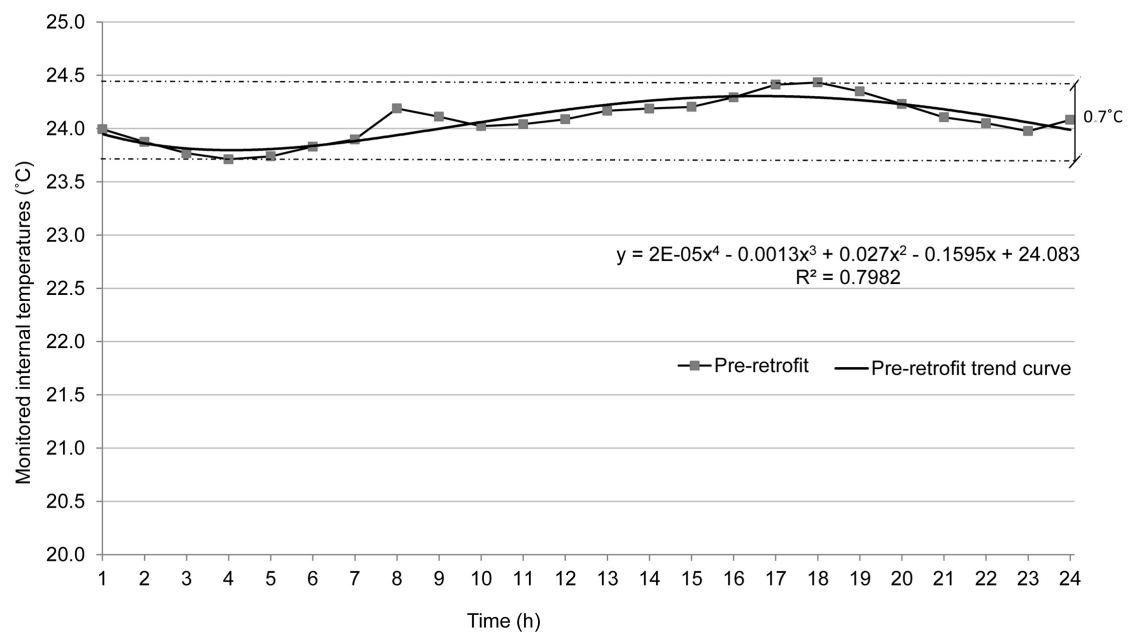

Figure 9: Internal temperature profile, pre-retrofit (non-standardised mean internal air temperature) $(\mathrm{n}=$ $9)$. 


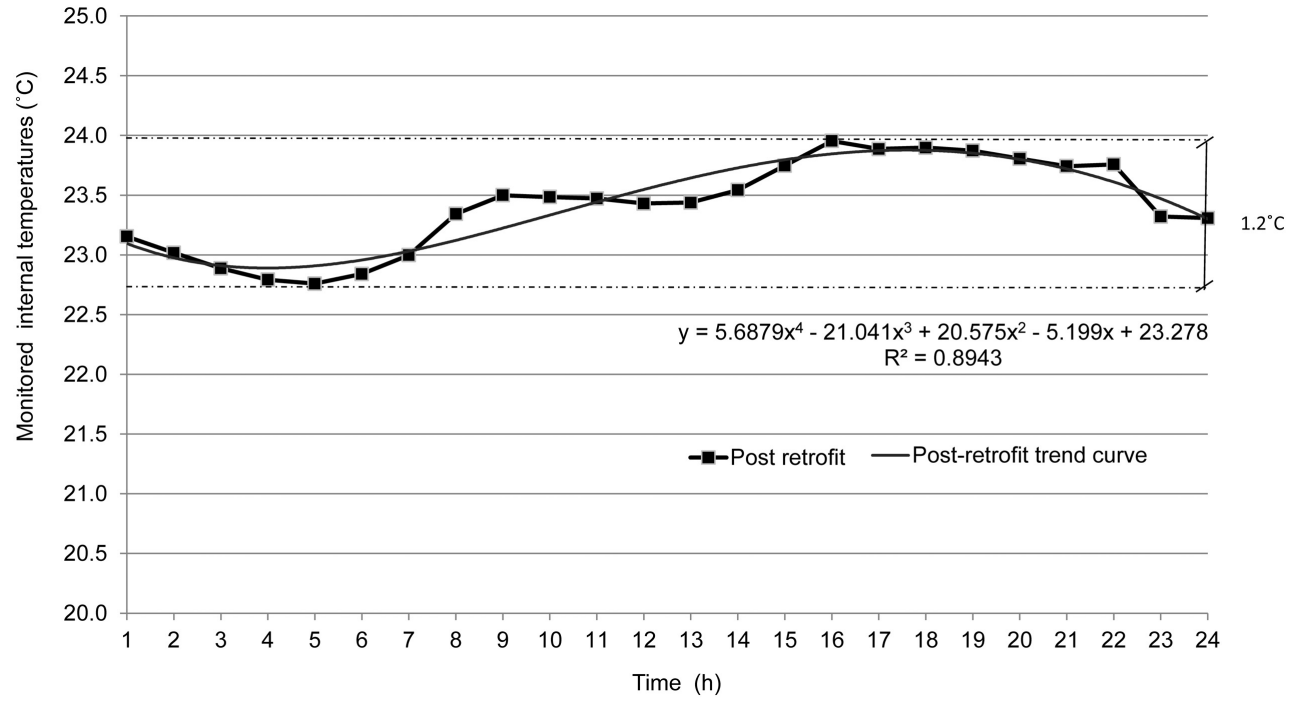

Figure 10: Internal temperature profile, post-retrofit (non-standardised mean internal air temperature) $(\mathrm{n}=$ $9)$.

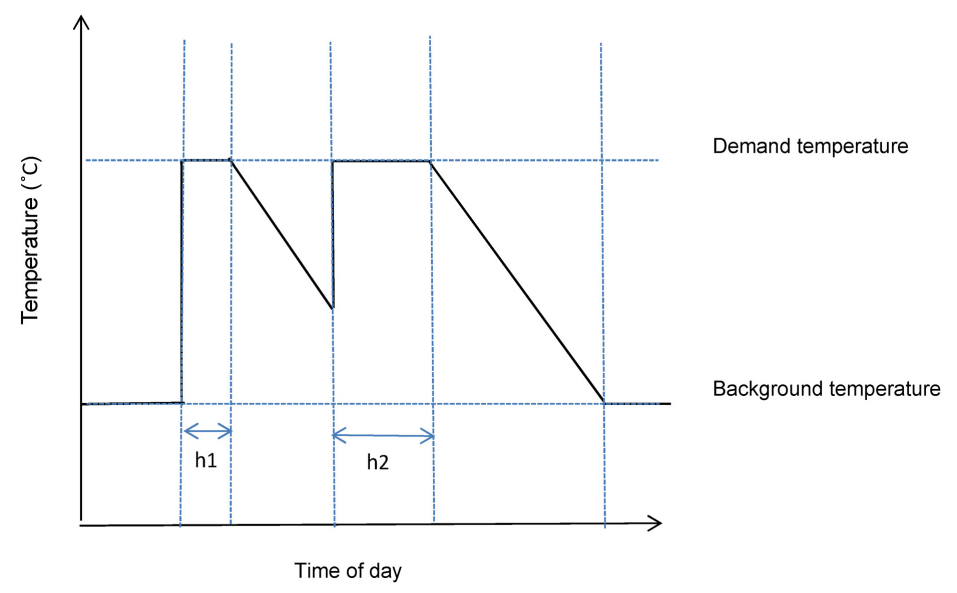

Figure 11: Internal temperature profile used in BREDEM-based model. Source: reproduced from Figure 10.1 of BREDEM-12 [21]. 


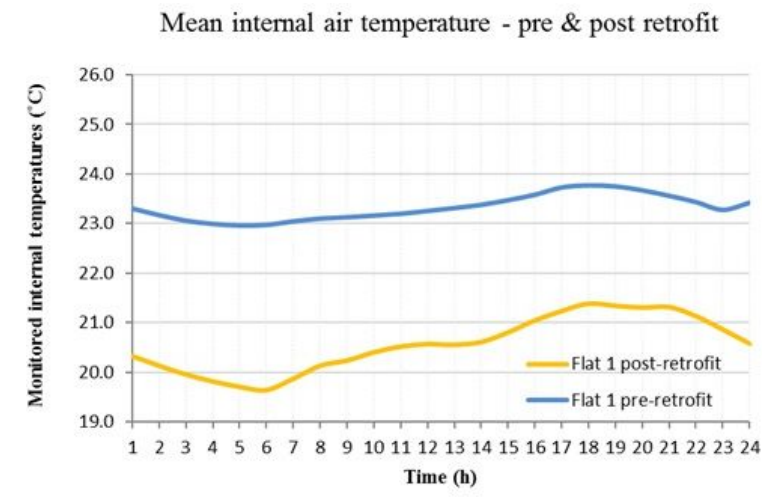

(a) Flat 1

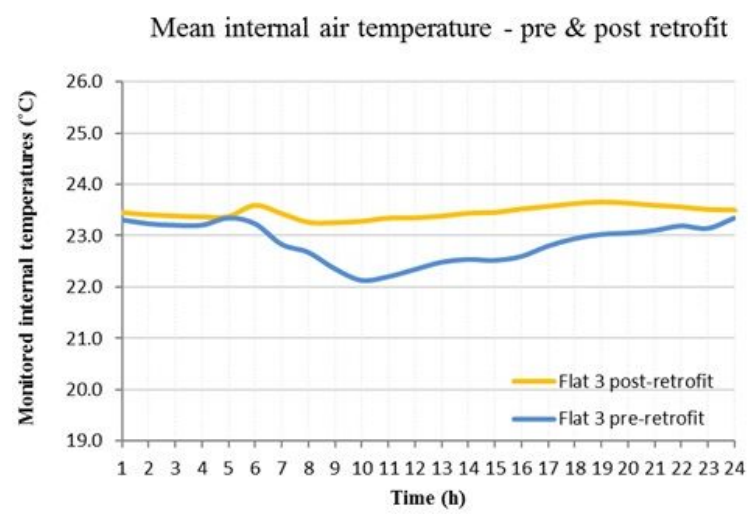

(c) Flat 3

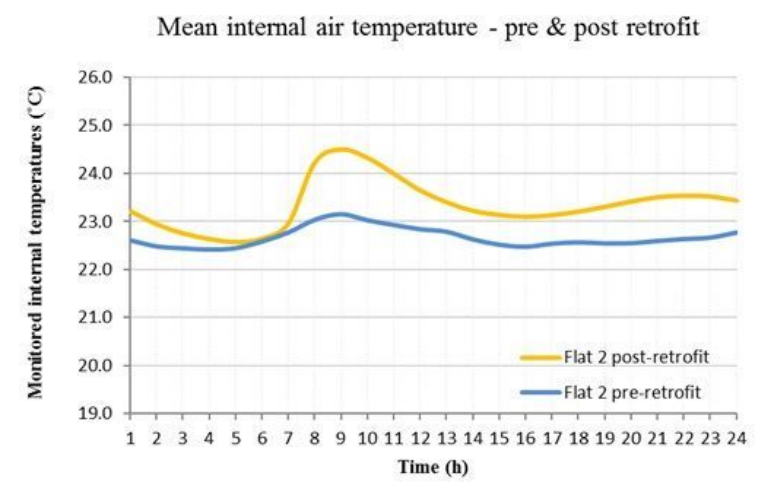

(b) Flat 2

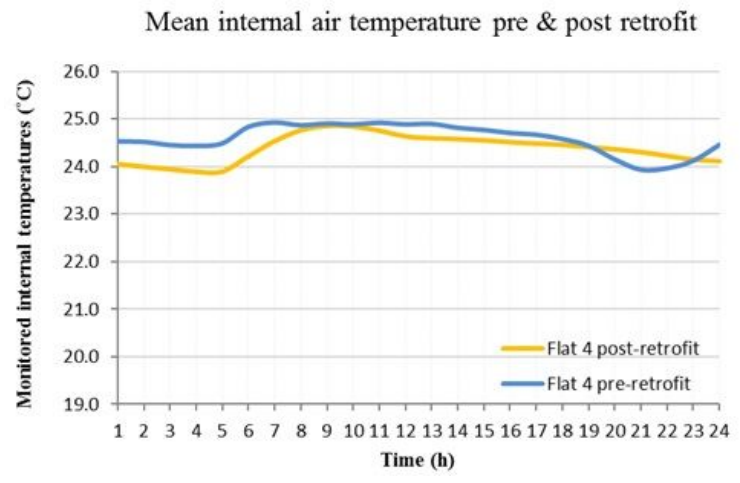

(d) Flat 4

Figure 12: Internal temperature profile, pre-retrofit and post-retrofit (non-standardised mean internal air temperature) per individual flat. 


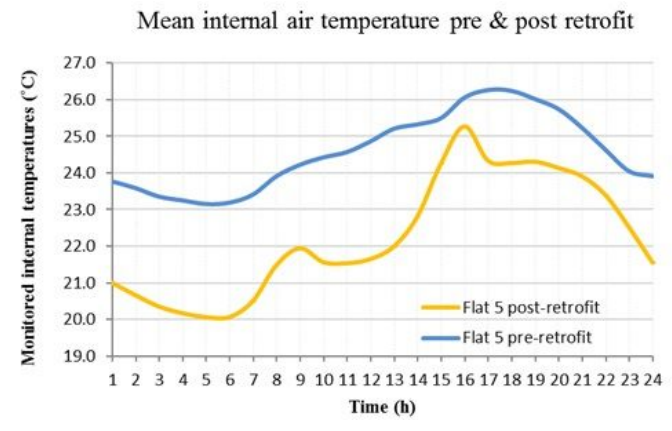

(a) Flat 5

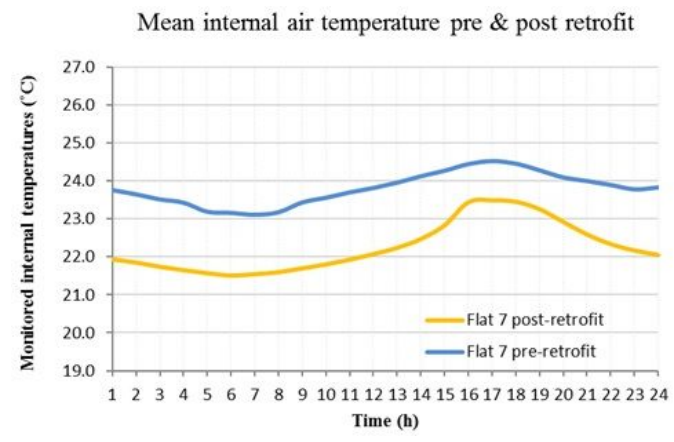

(c) Flat 7

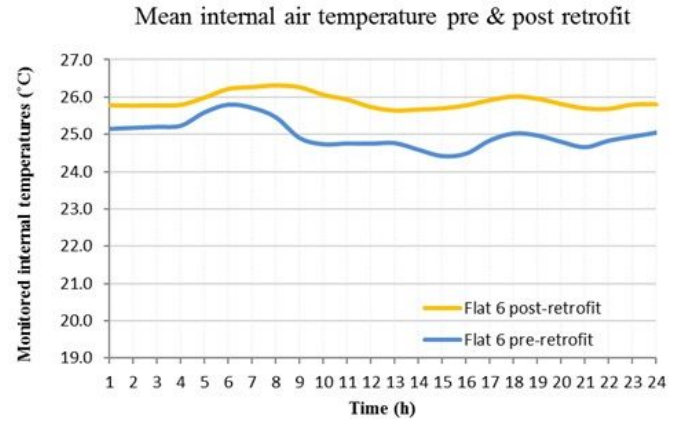

(b) Flat 6

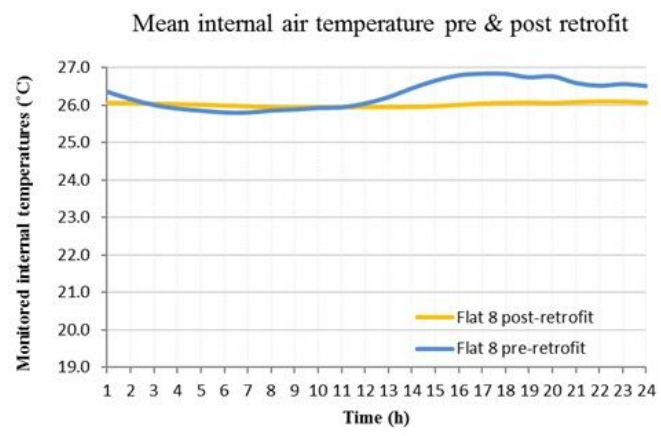

(d) Flat 8

Mean internal air temperature pre \& post retrofit

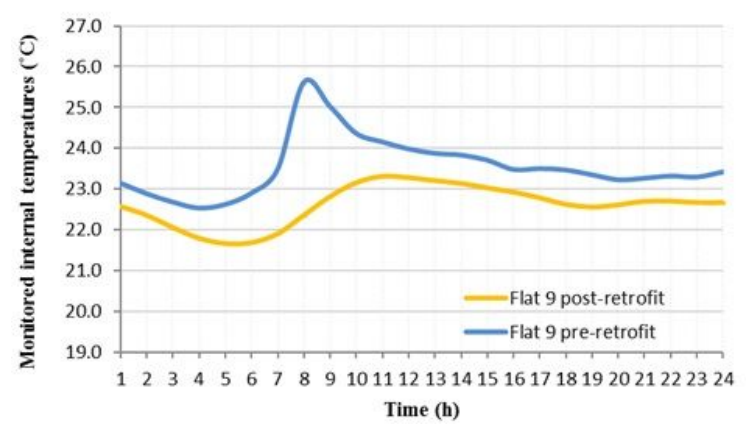

(e) Flat 9

Figure 13: Internal temperature profile, pre-retrofit and post-retrofit (non-standardised mean internal air temperature) per individual flat. 


\subsection{Space heating consumption}

Table 10 shows that the change in weather normalised space heating consumption following retrofit for the target building (76 flats) was $-27 \%$. Table 10 also shows that the change in mean space heating consumption in the control building (157 flats) during the same period was $7 \%$. As a result, the potential relative difference between target and control group was $-34 \%$.

At an individual dwelling level, Figure 14 and Figure 15 illustrate the monthly space heating consumption for nine dwellings surveyed in the case study pre- and post-retrofit.

Figures 14c, 14d, 15c, and 15d illustrate that these dwellings (Flat 3, 4, 7, and 8) are either not heated or have an extremely low pre and post retrofit space heating consumption. Thus, this denotes that fabric retrofit did not have an impact on space heating consumption on these flats as there is no heating demand before or after retrofit.

Figures $14 \mathrm{~b}$ and $15 \mathrm{a}$ depict that flat 2 and 5 have a low pre-retrofit space heating consumption and a quasi-flat post retrofit consumption. Similarly, Figure 15b and Figure 15e depict that flat 6 and 9 have a low pre-retrofit space heating consumption and a lower, null or very low, post-retrofit consumption. Thus, this suggests that there is a reduction of space heating consumption post-retrofit for Flat 2, 5,6 and 9. Table 8 describes the space heating profile description for dwellings $2,5,6$, and 9 .

Table 8: Space heating profile description dwellings 2, 5, 6, and 9.

\begin{tabular}{|c|c|}
\hline Dwelling & Space heating consumption profile description \\
\hline 2 (Figure 14b) & $\begin{array}{l}\text { Pre-retrofit. It consumed in March } 14.0 \mathrm{~kW} \mathrm{~h} \mathrm{~m}^{-2} \text { which decreased to } 7.0 \mathrm{~kW} \mathrm{~h} \mathrm{~m}^{-2} \text { by May } \\
\text { Post-retrofit. Space heating consumption followed a quasi-flat profile of } 5.0 \mathrm{~kW} \mathrm{~h} \mathrm{~m}^{-2}\end{array}$ \\
\hline 5 (Figure 15a) & $\begin{array}{l}\text { Pre-retrofit. It consumed in March } 9.0 \mathrm{~kW} \mathrm{~h} \mathrm{~m}^{-2} \text { which decreased to } 7.0 \mathrm{~kW} \mathrm{~h} \mathrm{~m}^{-2} \text { by May } \\
\text { Post-retrofit. Space heating consumption followed a quasi-flat profile of } 4.0 \mathrm{~kW} \mathrm{~h} \mathrm{~m}^{-2}\end{array}$ \\
\hline 6 (Figure 15b) & $\begin{array}{l}\text { Pre-retrofit. It consumed in March } 7.0 \mathrm{~kW} \mathrm{~h} \mathrm{~m}^{-2} \text { which decreased to } 2.0 \mathrm{~kW} \mathrm{~h} \mathrm{~m}^{-2} \text { in May } \\
\text { Post-retrofit. Space heating consumption in March was } 5.0 \mathrm{~kW} \mathrm{~h} \mathrm{~m}^{-2} \text { with a null demand in May }\end{array}$ \\
\hline 9 (Figure 15e) & $\begin{array}{l}\text { Pre-retrofit. It consumed in March } 8.0 \mathrm{~kW} \mathrm{~h} \mathrm{~m}^{-2} \text { which decreased to a very low } 1.0 \mathrm{~kW} \mathrm{~h} \mathrm{~m}^{-2} \text { in May } \\
\text { Post-retrofit. Space heating consumption in March was } 4.0 \mathrm{~kW} \mathrm{~h} \mathrm{~m}^{-2} \text { which decreased to a very low } 1.0 \mathrm{~kW} \mathrm{~h} \mathrm{~m}^{-2} \text { in May }\end{array}$ \\
\hline
\end{tabular}

Figure 14a show that flat 1 has pre-retrofit and post retrofit winter consumption followed by null demand in spring periods. See Table 9. Thus, this suggests that there is no reduction of space heating consumption post-retrofit for Flat 1.

Table 9: Space heating profile description dwelling 1.

\begin{tabular}{ll}
\hline Dwelling & \multicolumn{1}{c}{ Space heating consumption profile description } \\
\hline 1 (Figure 14a) & $\begin{array}{l}\text { Pre-retrofit. It consumed in March } 3.2 \mathrm{~kW} \mathrm{~h} \mathrm{~m}^{-2} \text { with a null demand between April and May } \\
\text { Post-retrofit.in March is about } 3.6 \mathrm{~kW} \mathrm{~h} \mathrm{~m}^{-2} \text { with a null demand between April and May }\end{array}$ \\
\hline \hline
\end{tabular}

Table 10: Weather normalised space heating consumption percentage change in target building, control building, and relative to each other

\begin{tabular}{l|c|c|c}
\hline & $\begin{array}{c}\text { Target Building } \\
\left(\mathrm{W} \mathrm{h} \mathrm{K}^{-1} \mathrm{~m}^{-2} \mathrm{~d}^{-1}\right)\end{array}$ & $\begin{array}{c}\text { Control Building } \\
\left(\mathrm{W} \mathrm{h} \mathrm{K}^{-1} \mathrm{~m}^{-2} \mathrm{~d}^{-1}\right)\end{array}$ & $\begin{array}{c}\Delta \text { (Target - Control) Building } \\
(\%)\end{array}$ \\
\hline Pre-retrofit & 0.0184 & 0.0460 & \\
Post-retrofit & 0.0134 & 0.0494 & -34 \\
\hline$\Delta($ Pre - Post)-retrofit (\%) & -27 & 7 & \\
\hline
\end{tabular}




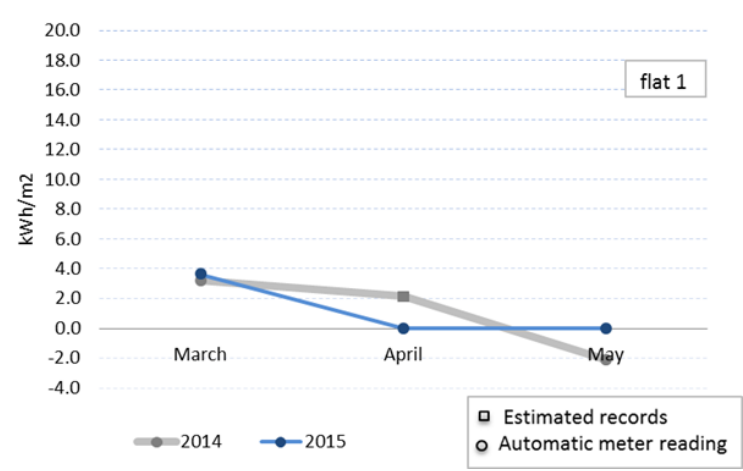

(a) Flat 1

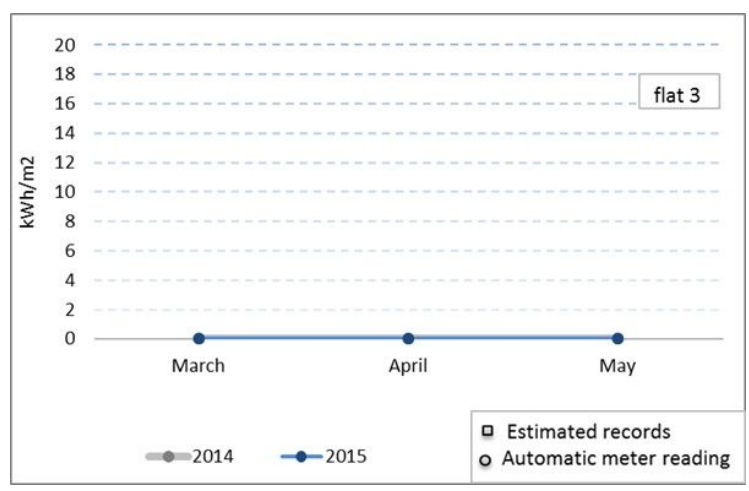

(c) Flat 3

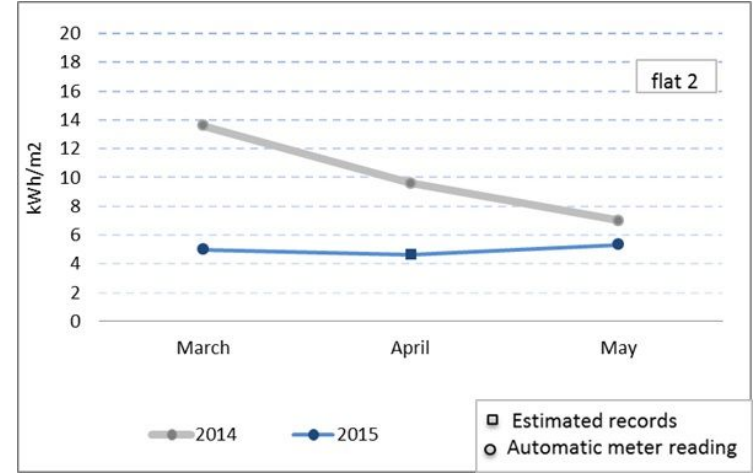

(b) Flat 2

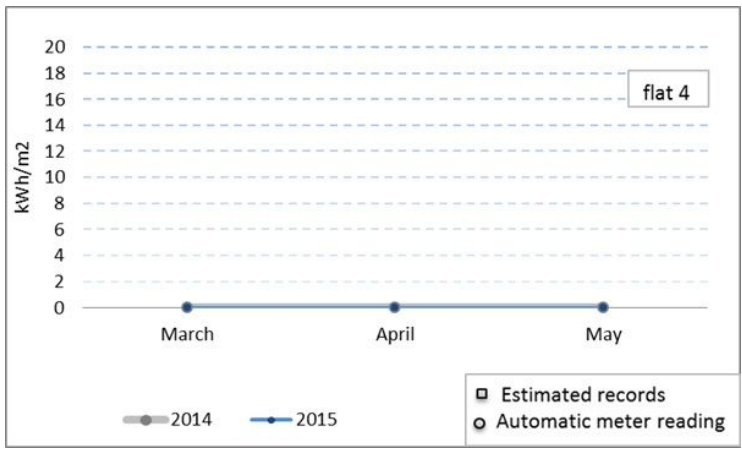

(d) Flat 4

Figure 14: Space heating consumption per individual flat. 


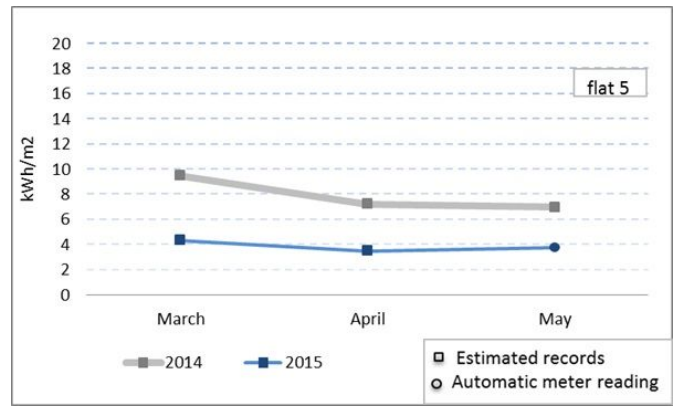

(a) Flat 5

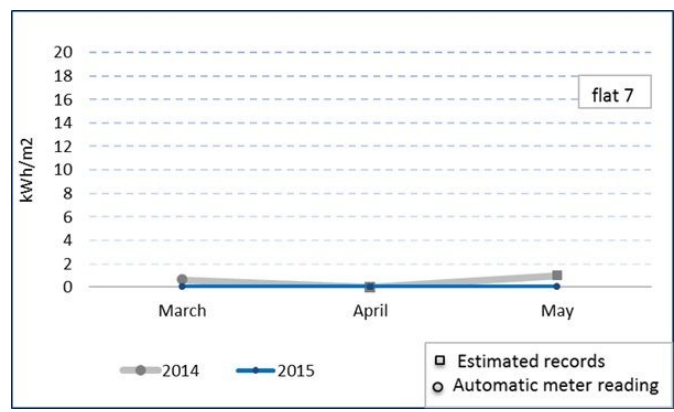

(c) Flat 7

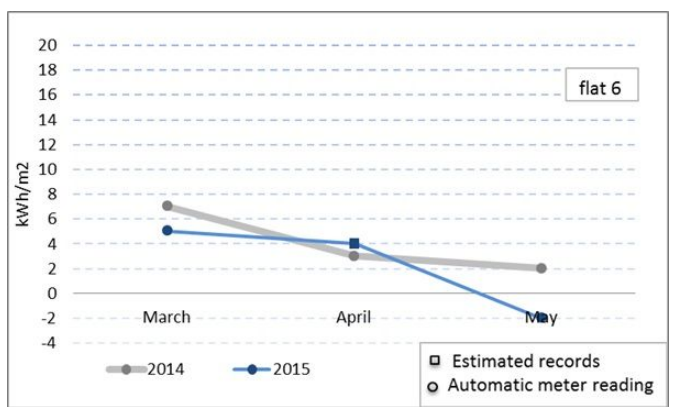

(b) Flat 6

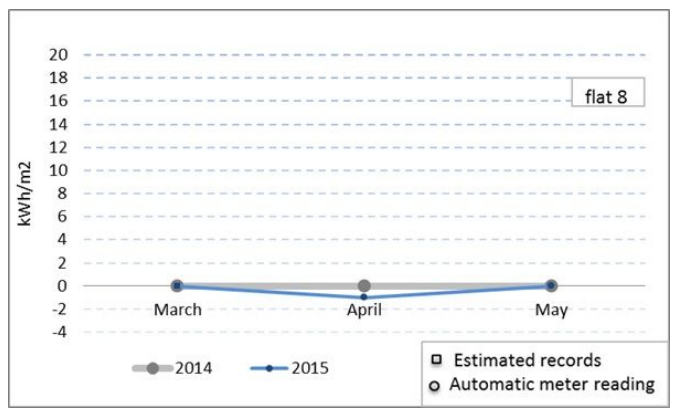

(d) Flat 8

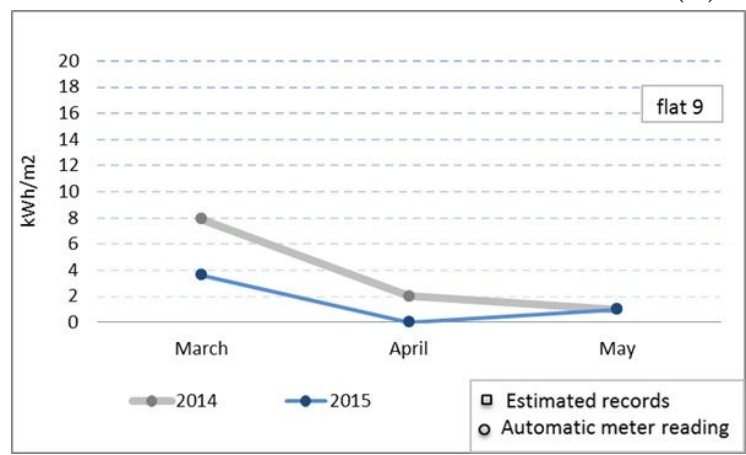

(e) Flat 9

Figure 15: Space heating consumption per individual flat. 


\subsection{Four aspects on the effects of building fabric retrofit}

In this section four thematic aspects of building fabric retrofit are discussed.

\subsubsection{Space heating}

The participants were asked to reflect on how their space heating use changed, or not, before and after retrofit. A significant number of interviewees reflected that there was no heating usage before the retrofit insulation or it was very low. For example, participant 7 (in flat 7) and 3 said they have never used the heating, before retrofit or after retrofit.

Other interviewees reflected that the heating usage was the same before and after retrofit and explained why. For example, participant 1 said he only switched the heating on in extreme cold days:

"Since March, which was the same with the previous system [referring to the heating periods], I don't have the heating on, more than one or two extreme, extremely cold days, which you will see on the survey (...)" (Participant 1).

Other participants also explained why their usage was low. For example, participant 5 attributed his low consumption because of the mild temperatures in 2015, describing 2015 as a good year. Participant 8, on the other hand, attributed her low consumption to flat location and building characteristics what means she benefits from when "people [other tenants] put the heating on".

Secondary heating

When participants were questioned on their use of secondary heating, they either did not mention it or stated that it was not used. For example participant 5 mentioned that although he owns a fire as a secondary heating source he could not afford to use it.

\subsubsection{Internal temperature sensation}

The participants were asked to reflect on how the temperature sensation was in their flats before and after retrofit. Responses have been grouped into: no change, too warm, and adequate.

\section{No change}

A significant group of participants felt that temperature sensation did not change following retrofit, they felt warm, before retrofit and after retrofit. For example, participant 1 explained that he did not feel any difference:

"It gets very warm all the year, but at the moment I cannot tell too much difference to be honest" (Participant 1).

Participant 8 stated that the temperature sensation was the same, before and after retrofit, as "it [the building] is always warm".

\section{Too warm}

Some participants reflected that the increased temperatures after retrofit was a cause for concern as "a cooler flat would be comfortable to them". In addition, how the retrofit insulation would work in the summer was also raised as a concern. For instance, participant 6 said: 
"the only thing that I don't know is when you get the summer, [as] it is really hot now (...)" (Participant 6).

\section{Adequate}

A small number of participants found that following retrofit the flats were adequately warm. They also felt that temperature sensation on the walls has improved as before retrofit "[the walls] always felt cold".

Table 11: Thermal comfort perception.

\begin{tabular}{ccc}
\hline Scale & $\begin{array}{c}\text { Before Retrofit } \\
\text { (Number Participants) }\end{array}$ & $\begin{array}{c}\text { After Retrofit } \\
\text { (Number Participants) }\end{array}$ \\
\hline Very Warm & 5 & 4 \\
Warm & 2 & 4 \\
Neutral & 1 & 1 \\
Cold & 1 & 0 \\
Very cold & 0 & 0 \\
\hline
\end{tabular}

Finally, the thermal comfort perception questionnaire carried out before and after retrofit illustrates that thermal comfort perception improved (when adding up number of participants feeling warm and very warm) from an already high baseline. For example, only 1 participant reported feeling cold before retrofit (see Table 11).

\subsubsection{Adaptive actions}

In the next paragraphs adaptive actions taken by the participants to adjust to the flat's temperature sensation are explored. These adaptive actions have been grouped into: window opening, fan use, and change of dressing practices.

\section{Window opening}

Window opening was perceived as a common practice by a significant number of participants before and after retrofit so as to obtain "fresh air". For instance, participant 1 described airing as a common routine before and after retrofit:

"(...) I tended to have at least one window open or a couple of windows open for ventilation in and out, (...) it hasn't changed, I'm still doing the same amount, and I can't notice any comparative difference at this stage" (Participant 1).

Other participants went further and stated that they have increased this practice following the building's fabric retrofit and had experienced difficulties cooling down the rooms if " it was windy outside" or due to a "night draught [when leaving windows open]" .

All in all, despite inducing draught and windy conditions, opening the windows was performed when it was felt too warm inside the flats and it was perceived as an essential aspect to control the temperature sensation.

\section{Fan use and dressing practices}

The increased temperatures had also triggered in some participants other adaptive actions such as use of fan and change in dressing practices. For instance, participant 2 and 7 said the increased temperatures drove the use of fan. Participant 9, on the other hand explained how the retrofit insulation had changed their dressing practice as now they can "walk around in t-shirt and shorts". 


\subsubsection{Building local characteristics}

\section{Heating system}

During the semi-structured interviews, a strong theme related to the building heating system was ascertained. Eloquently, participants explained how through the heating ducted air "a lot of heating is lost" and that brings the heat into their flats.

\section{Corridors}

Another aspect influencing the temperature sensation inside the flat was the temperature in the corridor. Participant 6 explained how the heat coming from the corridor to his flat changed the temperature sensation, feeling uncomfortable. This, in turn, triggers the need for the ventilation of the communal corridors by opening its windows to prevent heating building up.

\section{Aesthetics and noise}

Participants felt that the retrofit intervention on the building had an overall positive impact on the external appearance of the building. Table 12 summarises the participants' views. Finally, building occupants commented that the noise reduction was another positive impact derived from the retrofit intervention as windows were upgraded with 28-mm air-filled double-glazed unit. Participant 6 summarise the occupants' sentiment:

"when the windows are closed I can't hear any noise at all, that's good, it is really good, I'm very happy with the job" (Participant 6).

Table 12: Building external appearance perception.

\begin{tabular}{ccc}
\hline Scale & $\begin{array}{c}\text { Before Retrofit } \\
\text { (Number Participants) }\end{array}$ & $\begin{array}{c}\text { After Retrofit } \\
\text { (Number Participants) }\end{array}$ \\
\hline Very good & 0 & 5 \\
Good & 1 & 3 \\
Neutral & 2 & 0 \\
Bad & 3 & 1 \\
Very bad & 3 & 0 \\
\hline
\end{tabular}

The qualitative evidence provided in this section provides a more complete understanding of key factors affecting energy demand before and after retrofit for the case study. In the next section, the quantitative and qualitative results are discussed so as to explain the emerging phenomena.

\section{Discussion}

At first glance, the results of the upgrade appear to be a successful undertaking as there is an overall increased of internal air temperatures and a reduction of energy consumption for space heating after the energy-efficiency intervention. Specifically, Figure 6 shows an increase in mean internal air temperatures of $+0.46{ }^{\circ} \mathrm{C}$ (from $22.07^{\circ} \mathrm{C}$ to $22.53^{\circ} \mathrm{C}$ ) and Table 10 shows that the change in weather-normalised space heating consumption following retrofit for the target building (76 flats) was $-27 \%$ with a potential relative difference between target and control group of $-34 \%$. Thus, if only overall temperature figures are taken into account, it could be inferred that temperature take-back has taken place as there is a change (increase) 
in mean internal temperatures following the building fabric retrofit and the reduction in energy consumption saving associated with that change. In low-income households, in theory, this increase in temperature is likely due to an unmet demand for energy services, such as warmth, which needs to be satisfied. Thus, the energy saving lost to an increased of temperature could be calculated following [4] with approximately half of it apportioned to physical characteristics. However, the presented results in the form of individual flat and qualitative thematic data introduce significant observations and qualifying factors so as to discuss further whether or not temperature take-back is taking place.

\subsection{Temperature take-back and space heating consumption}

Individual dwelling data shows the increase in mean internal air temperature is not homogeneous. Nearly half of the flats experienced a decrease of temperature, this decrease was significant in most cases and ranged from a $-2.66^{\circ} \mathrm{C}$ or $-11.70 \%$ in Flat $1\left(22.74{ }^{\circ} \mathrm{C}\right.$ to $20.08^{\circ} \mathrm{C}$ see Figure $\left.7 \mathrm{a}\right)$ to a $-1.26{ }^{\circ} \mathrm{C}$ or $-5.57 \%$ in Flat $5\left(22.63^{\circ} \mathrm{C}\right.$ to $21.37^{\circ} \mathrm{C}$ see Figure $\left.8 \mathrm{a}\right)$.

In terms of space heating consumption, individual dwelling data (Flat 3, 4, 7, and 8. See Figures 14c, 14d, 15c, and 15d) denotes that fabric retrofit did not have an impact on space heating consumption on these flats as there is no heating demand before or after retrofit. Similarly, Figure 14a suggests that there is no reduction of space heating consumption postretrofit for Flat 1. Thus, the individual dwelling data indicates that less than half of the individual dwellings are experiencing a reduction of space heating consumption post-retrofit (Flat 2, 5, 6 and 9).

What is more, at an individual dwelling and building level, space heating consumption should be qualified. Table 13 shows the annualised gas consumption for an average property in England and Wales with the following characteristics: floor area $\left(50 \mathrm{~m}^{2}\right.$ or less), tenure (council housing), income (less than $£ 15,000$ per year), number of adults living at the residence ( 1 adult living at the property), and deprivation level (1st Quintile most deprived) for the years 2012 and 2013. This gas consumption is compared with the target building. The comparison shows that the target building dwellings consumed considerably less than an average national consumer, in each category and every year analysed. For instance, in 2013 this difference was more than $5000 \mathrm{~kW}$ h in each category. Thus, the presented weather normalised space heating consumption following retrofit for the target building of $-34 \%$ relative to the control building or at individual dwelling, when that occurs, could be seen as negligible. The qualitative thematic data further illustrates this as participants clearly say that they do not use the heating or when they do it is minimal and highly weather dependent:

"I don't have the heating on, over than one or two extreme, extremely cold days" (Participant 1).

Consequently, a negligible change in space heating consumption in absolute terms and a relatively small and non homogeneous (at dwelling level) change of internal air temperature suggest that temperature take-back is not taken place.

\subsection{Thermal comfort, saturation effect, upper level temperatures}

If it is assumed that $21.0^{\circ} \mathrm{C}$, the recommended temperature for healthy environments [29] (WHO guidelines [30] recommend $21.0^{\circ} \mathrm{C}$ in living rooms) is the maximum level of thermal 
Table 13: 2012 - 2013 England and Wales annualised mean gas consumption. ${ }^{*}$ Table 1: Gas consumption by floor area $\left(\mathrm{m}^{2}\right)$. ${ }^{* *}$ Table 9: Gas consumption by tenure. ${ }^{* * *}$ Table 11: Gas consumption by household income. ${ }^{* * * *}$ Table 13: Gas consumption by number of adults. ${ }^{* * * * *}$ Table 23: Gas consumption by Index of Multiple Deprivation (England) [28]

\begin{tabular}{|c|c|c|c|c|c|c|}
\hline & \multicolumn{6}{|c|}{ Annualised mean gas consumption (kW h) } \\
\hline Year & $\begin{array}{l}\text { Target building } \\
(\mathrm{n}=88)\end{array}$ & $\begin{array}{c}50 \mathrm{~m}^{2} \\
\text { or less * }\end{array}$ & $\begin{array}{c}\text { By tenure: } \\
\text { social housing ** }\end{array}$ & $\begin{array}{c}\text { By income: less than } \\
\text { less than } £ 15,000 \text { yearly }\end{array}$ & $\begin{array}{c}\text { By occupancy: } \\
1 \text { adult }\end{array}$ & $\begin{array}{l}\text { By deprivation index: } \\
\text { most deprived quintile } \\
\text { ****** }\end{array}$ \\
\hline 2012 & 1,632 & $7,400 \mathrm{~s}$ & 10,700 & 11,700 & 11,900 & 11,600 \\
\hline 2013 & 1,660 & $7,300 \mathrm{~s}$ & 9,800 & 11,200 & 11,400 & 11,100 \\
\hline
\end{tabular}

comfort then Figure 16 shows that this internal threshold temperature was achieved before retrofit $\left(22.07^{\circ} \mathrm{C}\right)$ and that the fabric efficiency upgrade increased the internal air temperature beyond that recommended threshold $\left(22.53^{\circ} \mathrm{C}\right)$. Moreover, $63 \%$ of the pre-upgrade recorded internal air temperatures were above $23.5^{\circ} \mathrm{C}$ (see Figure 16) is categorised by SAP-2012 as high risk of overheating [21] because during hot weather, it is more likely to be exposed to high internal temperatures [10].

Pre-retrofit, under standarised external conditions of $5^{\circ} \mathrm{C}$, the mean internal air temperature was $22.07^{\circ} \mathrm{C}$ with individual flat temperatures ranging ${ }^{1}$ from $20.93^{\circ} \mathrm{C}$ (Flat 3 see Figure 7c) to $22.74^{\circ} \mathrm{C}$ (Flat 1 see Figure 7a) and there is a negligible decrease in energy saving when compared to average national consumption as previously stated. Hereby, this paper argues that the saturation effect is taken place as suggested by Sorrel [4]. That is, "as pre-intervention room temperatures approach $21 \mathrm{C}$ the magnitude of temperature take-back decreases owing to saturation effects" [4, p. 26]. This implies that adding more energy efficiency measures (e.g. wall insulation, double glazing) to a household physical and heating system where indoor temperatures approach the maximum level for thermal comfort will yield a negligible decrease in energy saving consumption in absolute terms.

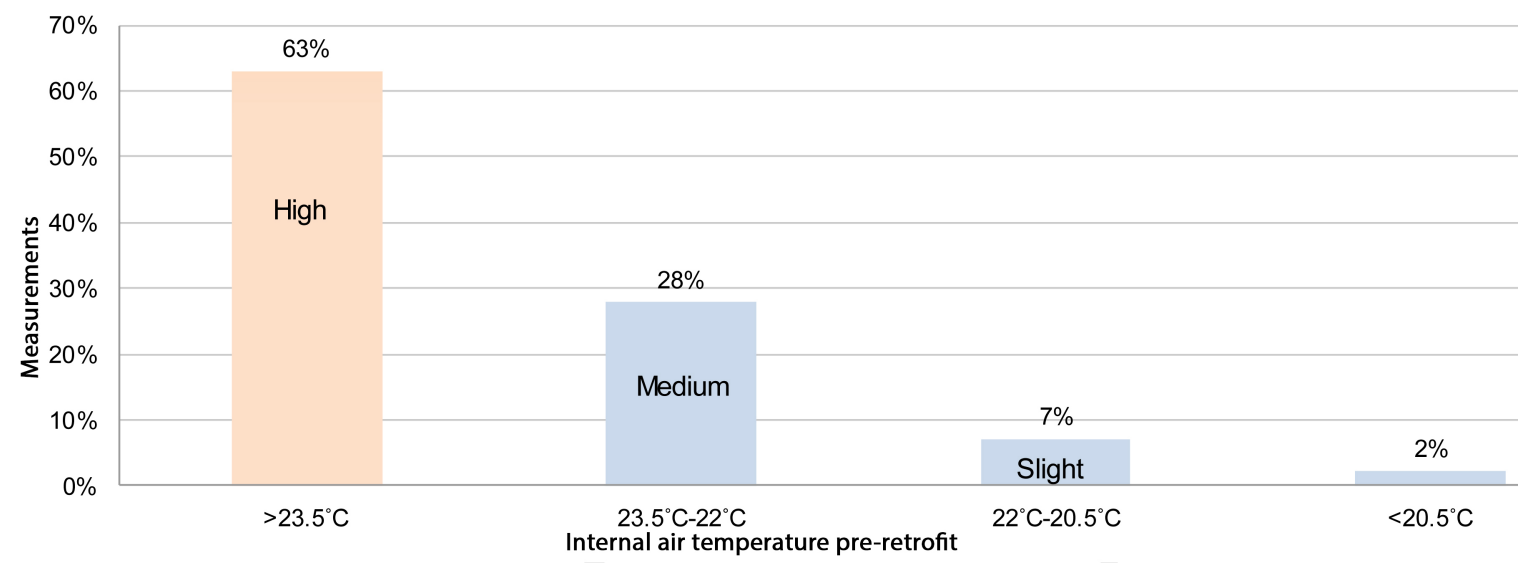

Figure 16: All flats $(\mathrm{n}=9)$ pre-retrofit recorded internal air temperatures.

Post-retrofit, under standardised external conditions of $5^{\circ} \mathrm{C}$, internal air temperatures in the target building were more than $3^{\circ} \mathrm{C}$ higher than, for instance, Oreszczyn et al. [7]

\footnotetext{
${ }^{1}$ both the minimum and maximum were excluded from the range
} 
as they reported $19.43^{\circ} \mathrm{C}$ compared to $22.53^{\circ} \mathrm{C}$ in this study. This is significant as similar studies [31,32] have indicated that temperature take-back is limited by an "upper level". This temperature may be taken as "neutral temperature that corresponding with a maximum 'take back' temperature" [31, p. 507]. This upper level or maximum take-back temperature has been reported at $21.0^{\circ} \mathrm{C}$ to $22.0^{\circ} \mathrm{C}$ by Shorrock and Utley [32] or at $22.5^{\circ} \mathrm{C}$ to $24.5^{\circ} \mathrm{C}$ for living rooms by Kavgic et al. [31]. When the qualitative data is examined, post-retrofit, it is clear that the majority of the occupants felt too warm or perceived no change in an already warmed dwellings. Further, there are a number of significant adaptive action reported: flat window opening, corridor window opening, use of fans, and changes of clothing. Window opening is particularly relevant in this context as it has been reported to be a good indicator of thermal performance. That is, Kavgic et al. [31] reported that $85 \%$ of occupants opened windows during the winter to regulate temperature (to increase air exchange rate for cooling down). In a similar high-rise social house building in the Riverside Dene after retrofit, the east facade had always more than $50 \%$ of windows opened, no matter the day or the time observed. The range was between 50\% and 95\% [33]. Thus, it is argued that the presented empirical evidence indicates that an upper level or maximum take-back temperature was achieved for the dwellings ranging ${ }^{2}$ from $20.85^{\circ} \mathrm{C}$ (Flat 7 see Figure $8 \mathrm{c}$ ) to $24.81^{\circ} \mathrm{C}$ (Flat 8 see Figure 8d)

\subsection{Physical and behavioural factors}

As initially presented, Sorrell [4] states that approximately half of temperature take-back can be apportioned to physical characteristics. Likewise, recent studies have theorised that occupants behaviour and (building) physical factors are linked. For example, [11] denotes the complex context in which retrofit insulation takes place - "a pre-existing set of interactions between occupants, heating systems and buildings - that is, a socio-technical system - the outcome will depend on how those interactions are changed by the retrofit and co-evolve afterwards" [11, p. 16]. Figure 9 and Figure 10 depict a quasi-flat internal air temperature profile and small maximum temperature differences pre- and post-retrofit. A flat internal temperature profile may denote the absence of occupant-controlled heating periods, and heating period length changes as defined by the BREDEM-12 heating profile [21] (see Figure 11 h1 and $\mathrm{h} 2$ heating period lengths). Consequently, this absence of pre- and post-retrofit heating periods suggest that the increase of standardised mean internal air temperature following the upgrade $\left(+0.46^{\circ} \mathrm{C}\right)$ may be the result of unheated periods. In other words, the increase of standardised mean internal air temperature appears to be more related to building-related physical processes rather than switching the heating on by occupants (occupant behaviour).

At individual dwelling level, however, the presented internal temperature profiles show that flats $(3,4,6$, and 8$)$ have no heating periods whereas others might have 1 or 2 heating periods. Furthermore, local building physical characteristics were a strong theme during the semi-structured interviews. In particular, aspects related to the heating system pipes losses (heating loss from the pipes), pipes placement within the building, and internal layout of communal areas and corridors. The connection between the heating pipes losses and building corridors was apparent and have a strong influence in the occupants' behaviour.

\footnotetext{
${ }^{2}$ both the minimum and maximum were excluded from the range
} 
"the heat is that way (...) as I said, because all the pipes (...) they run along there (...) which is obvious, because as soon as you open those door that conduct the corridor, you can feel the heat straight away anyway. " (Participant 4).

This means that the building has two "free heating zones" (heating pipework in vertical risers in main corridors serves horizontal runs on the $6^{\text {th }}, 7^{\text {th }}, 13^{\text {th }}$ and $14^{\text {th }}$ floors ) and interzone where the local building characteristics have strong influence on internal temperatures, space heating consumption, and the relationship between physical and behavioural factors (see Figure 17). Specifically, Figure 17b shows where the study flats are situated in those zones). As a result of this and the individual internal temperature profiles, behaviorual factors such as turning on the heating appear to be less relevant than physical factors such as energy-efficiency improvements to explain the increased of standardised mean internal air temperature but this is strongly influenced by the building local characteristics (e.g. free heating zones. See 3.3.4). Thus, it is unclear how much behavioural factors account for this and further research would be needed.

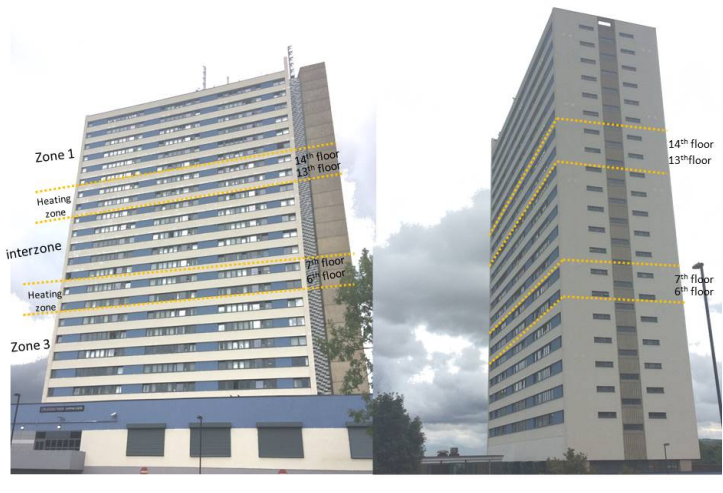

(a) Flat 1

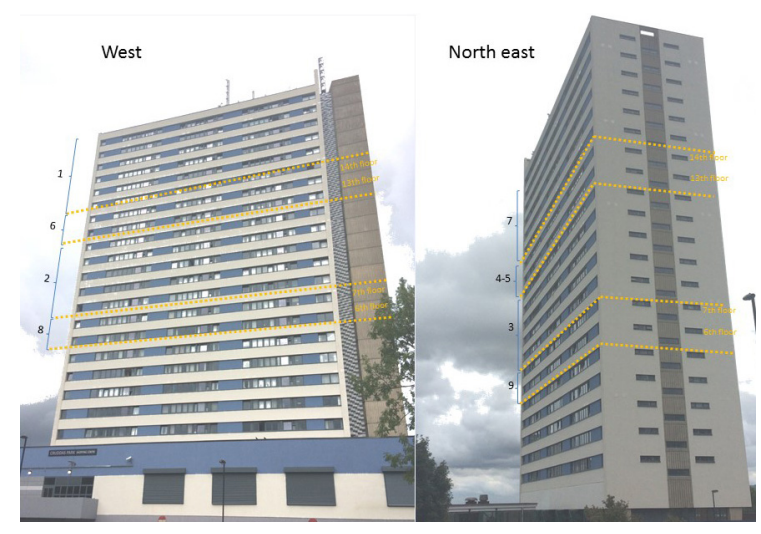

(b) Flat 2

Figure 17: Local building characteristics: heating zones due to heating pipes placement

\subsection{Policy implications}

In recent years academic discussions and policy-makers have expressed concern about temperature take-back of energy saving policies, which significantly reduce the impacts of energy efficiency programmes, specially, in low-income households in the UK. This study has observed that energy efficiency measures targeting low-income dwellings might achieve an unintended saturation of temperature. This, in turn, might prevent temperature take-back, achieving both thermal comfort and low-energy use. In light of this evidence, and if these results were more broadly corroborated, energy policy makers might need to revise some of their assumptions on take-back of energy saving space. For example, in the UK, the efficiency savings from the household measures for the ECO and Green Deal assumes a comfort taking factor of $15 \%$ (i.e. a $15 \%$ increase in their energy use) [34] and, as suggested in this paper, this might not be applicable to building retrofits where the saturation effect takes place. 
Thus, due to the high investment needed in high-rise building retrofit projects, at the local level there might be potential to develop an alternative retrofit policy guidelines where an energy and thermal comfort assessment from an external advisor can pre-test variables such as internal temperatures, heating system and building fabric performance, in order to suggest the best energy efficiency measure.

\section{Conclusion}

Understanding the effects of building fabric retrofit on social housing is an important and complex area of research. Empirically data-driven studies are needed as they have proven valuable in appraising the energy efficiency measures on internal dwelling conditions.

The evidence presented in this paper is based on one specific, detailed, and contextualised case. The presented results suggests that, first, contrary to the social housing provider's expectations, temperature take-back as extra warmth (or energy consumption savings) has not taken place. Second, an unintended saturation effect has taken place. This supports the assumption that temperature take-back decreases owing to saturation effects when preintervention internal temperatures saturate (approaching $21^{\circ} \mathrm{C}$ ) in lieu of the hypothesis that low-income householders take the benefits of an energy efficiency intervention as extra warmth rather than energy savings. Third, an upper level or maximum take-back temperature was achieved for the dwellings ranging from $20.85{ }^{\circ} \mathrm{C}$ (Flat 7 see Figure 8c) to $24.81{ }^{\circ} \mathrm{C}$ (Flat 8 see Figure 8d). Fourth, behavioural factors such as turning on the heating appear to be less relevant than physical factors such as energy-efficiency improvements to explain the increased of standardised mean internal air temperature. However, it is unclear how much behavioural factors account for this and further research would be needed. The study also suggests that local building characteristics such as location of heat pipes (and their associated heat loss) play a significant role. Thus, if these results were more broadly confirmed, future local guidelines to evaluate appropriateness of energy-efficiency interventions should take into account pre-intervention variables such as internal temperatures, heating system and building fabric performance, in order to suggest the best energy efficiency measure.

\section{Acknowledgements}

We would like to thank all the Riverside Dene residents, Your Homes Newcastle (Tom Jarman specially), and Newcastle City Council for their support to carry out this research study.

\section{References}

\section{References}

[1] T. Oreszczyn, R. Lowe, hallenges for energy and buildings research: objectives, methods and funding mechanisms, Building Research \& Information 38 (1) (2010) 107-122, doi: 10.1080/09613210903265432.

[2] D. Teli, T. Dimitriou, P. James, A. Bahaj, L. Ellison, A. Waggott, Fuel poverty-induced 'prebound effect' in achieving the anticipated carbon savings from social housing retrofit, 
Building Services Engineering Research and Technology 37 (2) (2015) 176-193, doi: $10.1177 / 0143624415621028$.

[3] G. Milne, B. Boardman, Making cold homes warmer: the effect of energy efficiency improvements in low-income homes A report to the Energy Action Grants Agency Charitable Trust, Energy Policy 28 (6) (2000) 411-424, ISSN 0301-4215.

[4] S. Sorrell, The Rebound Effect: An Assessment of the Evidence for Economy-wide Energy Savings from Improved Energy Efficiency, techreport, The UK Energy Research Centre, URL http://www .ukerc.ac.uk/programmes/technology-and-policy-assessment/the-rebound-effec 2007.

[5] W. Poortinga, S. Jiang, C. Grey, C. Tweed, Impacts of energy-efficiency investments on internal conditions in low-income households, Building Research \& Information (2017) 1-15doi:10.1080/09613218.2017.1314641.

[6] S. Sorrell, J. Dimitropoulos, M. Sommerville, Empirical estimates of the direct rebound effect: A review, Energy Policy 37 (4) (2009) 1356-1371, ISSN 0301-4215, doi:10.1016/j.enpol.2008.11.026, URL http://www.sciencedirect.com/science/article/pii/S0301421508007131.

[7] T. Oreszczyn, S. H. Hong, I. Ridley, P. Wilkinson, Determinants of winter indoor temperatures in low income households in England, Energy and Buildings 38 (3) (2006) 245-252, ISSN 0378-7788, doi:http://dx.doi.org/10.1016/j.enbuild.2005.06.006, URL http://www.sciencedirect.com/science/article/pii/S0378778805000964.

[8] C. Sanders, M. Phillipson, An Analysis of the Difference between Measured and Predicted Energy Savings when Houses are Insulated, Centre for Research on Indoor Climate and Health, Glasgow Caledonian University; 2006. .

[9] S. H. Hong, J. Gilbertson, T. Oreszczyn, G. Green, I. Ridley, A field study of thermal comfort in low-income dwellings in England before and after energy efficient refurbishment, Building and Environment 44 (6) (2009) 1228-1236, ISSN 0360-1323, doi: 10.1016/j.buildenv.2008.09.003.

[10] ZCH, Defining overheating. Evidence Review, Report, Zero Carbon Hub, 2015.

[11] J. Love, Understanding the interactions between occupants, heating systems and building fabric in the context of energy efficient building fabric retrofit in social housing., Thesis, UCL Energy Institute, 2014.

[12] S. Sorrell, Reducing energy demand: A review of issues, challenges and approaches., Renewable and Sustainable Energy Reviews 47 (2015) 74-82, doi: 10.1016/j.rser.2015.03.002, URL https://doi.org/10.1016/j.rser.2015.03.002.

[13] S. H. Hong, Changes in space heating energy consumption following energy efficient refurbishment in low-income dwellings in England, Thesis, The Barlett School of Graduate Studies, University Colleage London., 2011. 
[14] L. Doyle, A.-M. Brady, G. Byrne, An overview of mixed methods research - revisited, Journal of Research in Nursing 21 (8) (2016) 623-635, doi:10.1177/1744987116674257.

[15] L. V. Madsen, K. Gram-Hanssen, Understanding comfort and senses in social practice theory: Insights from a Danish field study, Energy Research \& Social Science 29 (2017) 86-94, doi:http://dx.doi.org/10.1016/j.erss.2017.05.013.

[16] S. Muthesius, M. Glendinning, Tower Block: Modern Public Housing in England, Scotland, Wales and Northern Ireland, Yale University Press, ISBN 978-0300054446, 1993.

[17] YHN, Cruddas Park demographic, unpublished document, 2015.

[18] Powering up for UK district heating project, World Pumps 2012 (8) (2012) 22-23, doi: https://doi.org/10.1016/S0262-1762(12)70215-8.

[19] ISO, Ergonomics of the thermal environment - Instruments for measuring physical quantities. BS EN 7726:2001, techreport ISBN: 0580386511, British Standards., 2001.

[20] NASA, AtmosModeler. Temperature and Altitude., National Aeronautics and Space Administration (NASA) web page., URL http://bit.do/efZwT, last accessed 10, May $2018,2018$.

[21] B. R. Anderson, P. F. Chapman, N. G. Cutland, C. M. Dickson, S. M. Doran, J. H. Henderson, G.and Henderson, P. J. Iles, L. Kosmina, L. D. Shorrock, BREDEM-12 Model description: 2001 update., Report, Building Research Establishment, Department for Environment, Food and Rural Affairs., 2002.

[22] S. H. Hong, T. Oreszczyn, I. Ridley, The impact of energy efficient refurbishment on the space heating fuel consumption in English dwellings, Energy and Buildings 38 (10) (2006) 1171-1181, ISSN 0378-7788, doi:http://dx.doi.org/10.1016/j.enbuild.2006.01.007, URL http://www.sciencedirect.com/science/article/pii/S0378778806000399.

[23] V. Braun, V. Clarke, Using thematic analysis in psychology, Qualitative Research in Psychology 3 (2) (2006) 77-101, doi:10.1191/1478088706qp063oa.

[24] M. Frondel, C. M. Schmidt, Evaluating environmental programs: the perspective of modern evaluation research., Ecological Economics 55 (2005) 515-526.

[25] T. D. N. U. Cook, R. William, J. T. U. of Memphis) Shadish, D. T. L. U. Campbell, Experimental and Quasi-Experimental Designs for Generalized Causal Inference, Cengage Learning, Inc, ISBN 0395615569, 2001.

[26] DECC, What people want from their heating controls: a qualitative study, Tech. Rep., Departement of Energy and Climate Change (DECC), URL https://www.gov.uk/government/publications/what-people-want-from-their-heating-contr 2013. 
[27] G. M. Huebner, M. McMichael, D. Shipworth, M. Shipworth, M. Durand-Daubin, A. Summerfield, The reality of English living rooms - A comparison of internal temperatures against common model assumptions, Energy and Buildings 66 (2013) 688-696, doi:10.1016/j.enbuild.2013.07.025.

[28] DECC, The Future of Heating: Meeting the challenge., Tech. Rep., Department of Energy and Climate Change (DECC), London, URL goo.gl/iiv4bp, 2013.

[29] DCLG, Housing health and safety rating system- guidance for landlords and property related professionals, techreport ISBN 9781851128563, Department for Communities and Local Goverment (DCLG), 2006.

[30] W. H. Organization, Health Impact of Low Temperatures, Tech. Rep., WHORegional Office for Europe, Copenhagen, 1987.

[31] M. Kavgic, A. Summerfield, D. Mumovic, Z. Stevanovic, V. Turanjanin, Z. Stevanovic, Characteristics of indoor temperatures over winter for Belgrade urban dwellings: Indications of thermal comfort and space heating energy demand, Energy and Buildings 47 (2012) 506-514, doi:https://doi.org/10.1016/j.enbuild.2011.12.027.

[32] L. D. Shorrock, J. I. Utley, Domestic Energy Fact File, Tech. Rep., Building Research Establishment, 2003.

[33] Papantoniou, Impact of Natural Ventilation on high-rise social housing buildings, in Newcastle Upon Tyne, UK, Ph.D. thesis, School of Architecture, Planning and Landscape. Newcastle University., 2015.

[34] DECC, Estimated impacts of energy and climate change policies on energy prices and bills: 2014, Tech. Rep., Department of Energy and Climate Change (DECC), 2014.

\section{Appendix A}

\section{Detail description of measurement devices' specifications}

Table 14: Table Gemini data logger specifications

\begin{tabular}{l|c|c}
\hline & $\begin{array}{c}\text { Tinytag Plus 2 (external temperature) } \\
\text { TGP-4017 }\end{array}$ & $\begin{array}{c}\text { Tinytag Transit 2 (internal temperature) } \\
\text { TG-4080 }\end{array}$ \\
\hline Temperature range & $-40^{\circ} \mathrm{C}$ to $85^{\circ} \mathrm{C}$ & $-40^{\circ} \mathrm{C}$ to $70^{\circ} \mathrm{C}$ \\
\hline Sensor type & $10 \mathrm{~K}$ NTC Thermistor (Internally mounted) \\
Reading resolution & \multicolumn{2}{|c}{$0.01^{\circ} \mathrm{C}$ or better } \\
Logging interval & $0.01 \mathrm{~s}-10$ days \\
\hline
\end{tabular}

